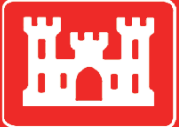

US Army Corps of Engineers ${ }_{\circledast}$ Engineer Research and Development Center

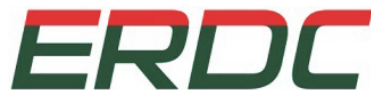

INNOVATIVE SOLUTIONS for a safer, better world

Coastal Inlets Research Program

\title{
Pilot Study Evaluating Nearshore Sediment Placement Sites, Noyo Harbor, CA
}

Lihwa Lin, Honghai Li, Mitchell E. Brown, Frank Wu,

February 2013 and Lisa Andes

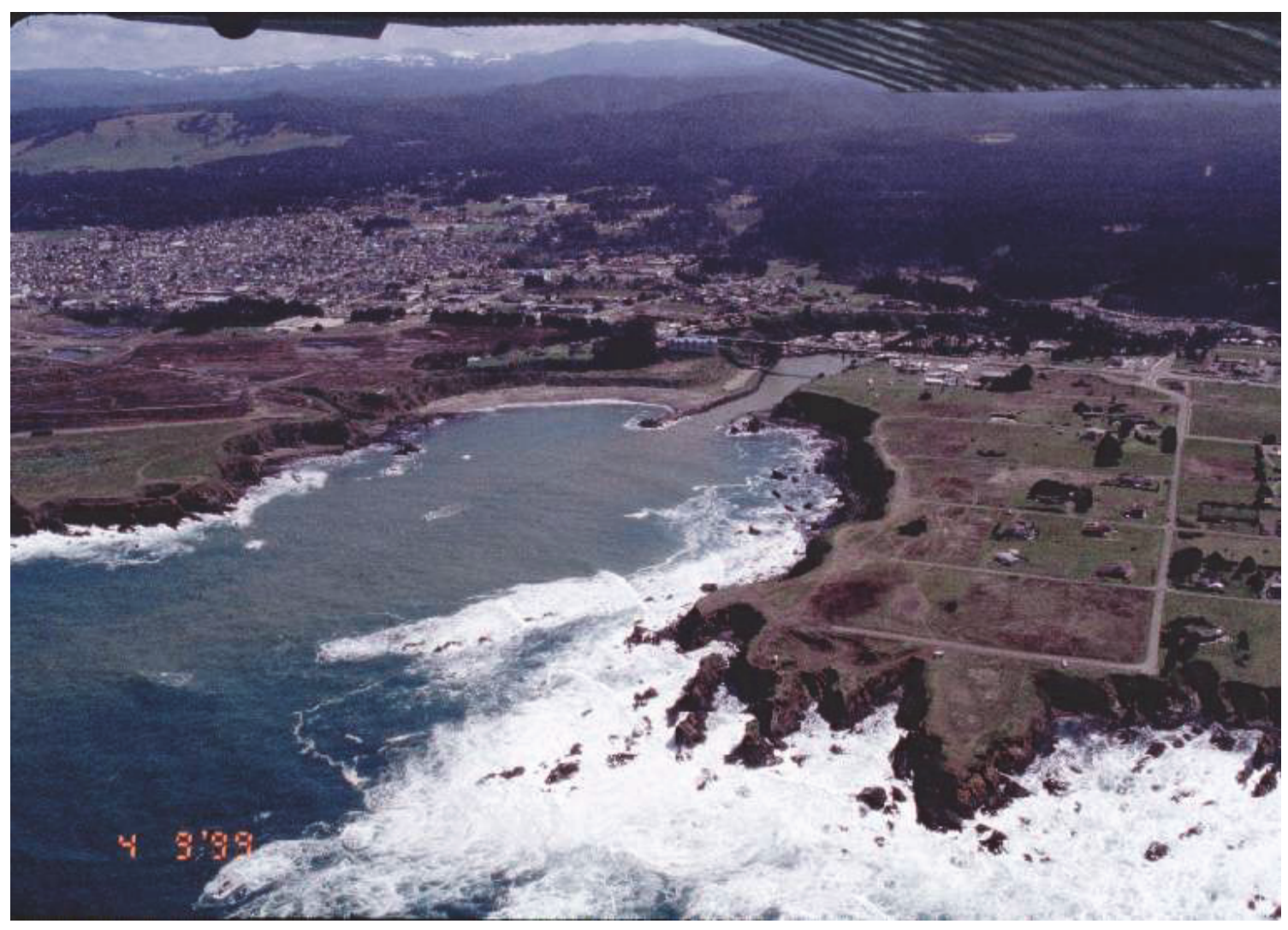

Mouth of Noyo River, CA (photograph courtesy of www.krisweb.com). 
The US Army Engineer Research and Development Center (ERDC) solves the nation's toughest engineering and environmental challenges. ERDC develops innovative solutions in civil and military engineering, geospatial sciences, water resources, and environmental sciences for the Army, the Department of Defense, civilian agencies, and our nation's public good. Find out more at www.erdc.usace.army.mil.

To search for other technical reports published by ERDC, visit the ERDC online library at http://acwc.sdp.sirsi.net/client/default. 


\title{
Pilot Study Evaluating Nearshore Sediment Placement Sites, Noyo Harbor, CA
}

\author{
Lihwa Lin, Honghai Li, and Mitchell E. Brown \\ Coastal and Hydraulics Laboratory \\ U.S. Army Engineer Research and Development Center \\ 3909 Halls Ferry Road \\ Vicksburg, MS 39180-6199, USA \\ Frank Wu and Lisa Andes \\ U.S. Army Engineer District, San Francisco \\ 1455 Market Street \\ San Francisco, CA 94103, USA
}

Final report

Approved for public release; distribution is unlimited.
Prepared for US Army Engineer District, San Francisco 1455 Market Street
San Francisco, CA 94103




\section{Abstract}

The US Army Engineer District, San Francisco (SPN) and the Coastal Inlets Research Program conducted a pilot study to consider various placement locations for dredged material in vicinity of Noyo Harbor, CA. Approximately 30,000-40,000 cu yd/yr of beach-quality sediment is dredged from the navigation channel and the lower Noyo River, located on the north central California coast. The pilot study investigated several potential locations for placement of dredged sediments in one of two areas north of Noyo Bay. The investigation included field data collection and numerical modeling of near-field sediment transport and suspended sediment concentration during and after placement of the dredged sediments under combined wave and current conditions. The numerical model provided the technical information necessary for SPN and Noyo Harbor stakeholders to evaluate a location site that is economically feasible for the optimum sediment placement. Upon acceptance by the stakeholders and receipt of additional funds, a demonstration project will be conducted, and the Dredged Material Management Plan (DMMP) for Noyo Harbor will be updated to include a beneficial use site for nearshore placement.

DISCLAIMER: The contents of this report are not to be used for advertising, publication, or promotional purposes. Citation of trade names does not constitute an official endorsement or approval of the use of such commercial products. All product names and trademarks cited are the property of their respective owners. The findings of this report are not to be construed as an official Department of the Army position unless so designated by other authorized documents. 


\section{Contents}

Abstract...................................................................................................................................... if

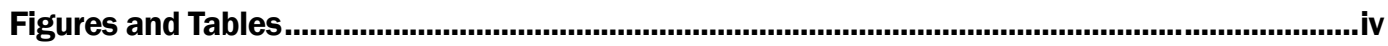

Preface ...............................................................................................................................................vi

Unit Conversion Factors.......................................................................................................vii

1 Introduction......................................................................................................................... 1

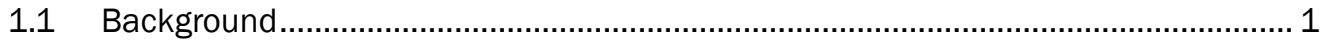

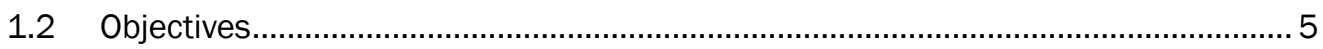

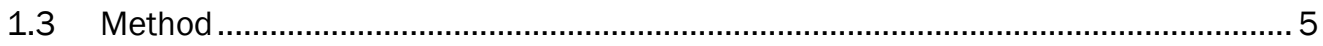

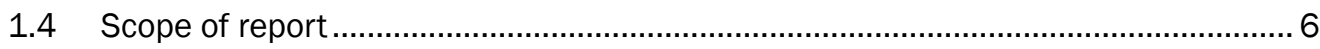

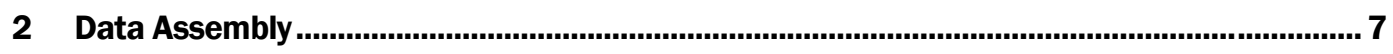

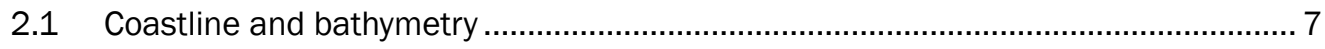

2.2 Wind and wave data .............................................................................................. 8

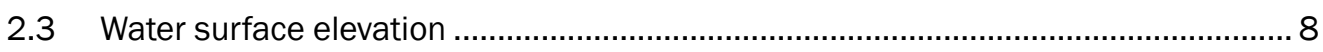

2.4 Sediment characteristics .................................................................................. 10

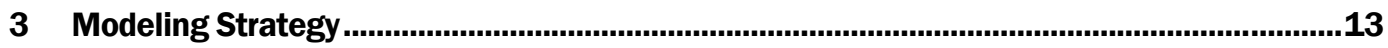

3.1 Model description ......................................................................................... 13

3.2 Model domain ................................................................................................. 14

3.3 Simulation period and model forcing ................................................................ 15

P.4 Potential placement sites.................................................................................... 15

3.5 Model simulation settings ......................................................................... 18

4 Results and Discussion........................................................................................................21

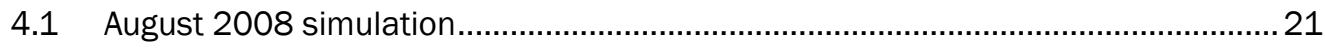

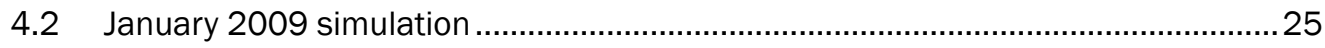

4.3 Comparison of calculated morphology change.....................................................28

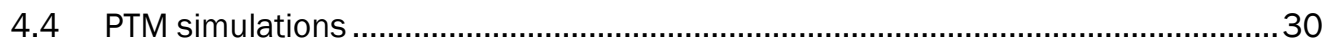

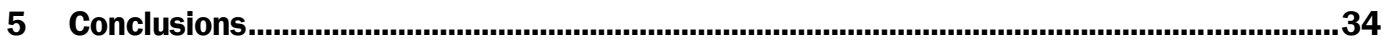

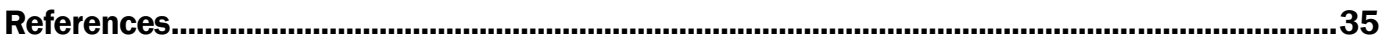

\section{Report Documentation Page}




\section{Figures and Tables}

\section{Figures}

Figure 1. Location map of Noyo and Ten Mile River, CA. ……...................................................... 2

Figure 2. Noyo, Fort Bragg, and MacKerricher State Park, Mendocino County, CA............................. 4

Figure 3. Noyo Bay and coast bathymetry contours in ft related to MSL........................................... 7

Figure 4. Noyo Bay bathymetry (depth contour increment in $15 \mathrm{ft}$ ) and aerial photo........................ 8

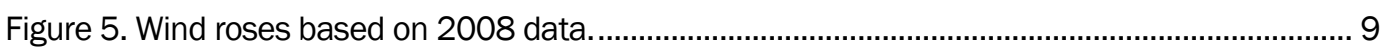

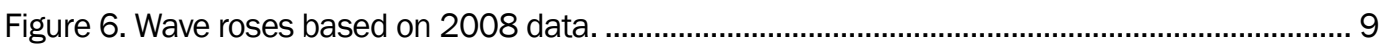

Figure 7. Monthly mean wave height at Buoys 46014, 46022, and 46213 for 2008. ................... 10

Figure 8. Time series of water levels at NOAA Stations 9416841 and 9418767 for April and December 2008.

Figure 9. Significant wave height, peak wave period, mean wave direction, wind speed, and wind direction from Buoys 46014, 46022, and 46213, August 2008.................................... 16

Figure 10. Significant wave height, peak wave period, mean wave direction, wind speed, and wind direction from Buoys 46014 and 46213, January 2009.

Figure 11. Time series of water levels at NOAA Stations 9416841 for August 2008 and January 2009 used as the boundary condition for CMS. ........................................................... 18

Figure 12. Three potential placement sites for dredge material. ....................................................... 19

Figure 13. Potential sites 1 and 2 for CMS simulation................................................................. 20

Figure 14. Calculated strong sediment concentration pattern from Site 1 placement without wave forcing for August 2008.

Figure 15. Calculated strong sediment concentration pattern from Site 2 placement without wave forcing for August 2008

Figure 16. Calculated strong sediment concentration pattern with wave forcing for August 2008.

Figure 17. Calculated sediment accretion/erosion field at Site 1 without wave forcing for August 2008.

Figure 18. Calculated sediment accretion/erosion field at Site 2 without wave forcing for August 2008.

Figure 19. Calculated sediment accretion/erosion field with wave forcing for August 2008........... 24

Figure 20. Calculated strong sediment concentration pattern from Site 1 placement without wave forcing for January 2009.

Figure 21. Calculated strong sediment concentration pattern from Site 2 placement without wave forcing for January 2009.

Figure 22. Calculated strong sediment concentration pattern from Site 1 or 2 placement with wave forcing for January 2009.

Figure 23. Calculated sediment accretion/erosion field at Site 1 without wave forcing for January 2009.

Figure 24. Calculated sediment accretion/erosion field at Site 2 without wave forcing for January 2009. 
Figure 25. Calculated sediment accretion/erosion field with wave forcing for January

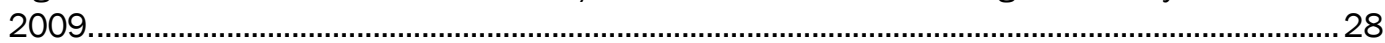

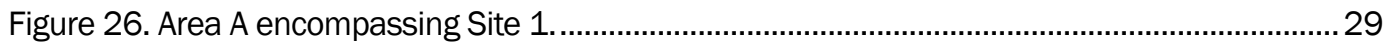

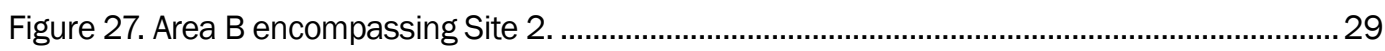

Figure 28. Calculated clay particle distribution at the end of the release (day 12)........................ 31

Figure 29. Calculated clay particle distribution at the end of simulation (day 30)...........................32

Figure 30. Calculated silt particle distribution at the end of the release (day 12). ..........................32

Figure 31. Calculated silt particle distribution at the end of simulation (day 30)............................33

\section{Tables}

Table 1. NDBC, CDIP, and NOAA station locations. .................................................................. 11

Table 2. Grain grain sizes of sediment samples taken in Noyo Harbor channels............................. 12

Table 3. Mean and maximum significant wave heights from Buoys 46014, 46022, and 46213 for August 2008 and January 2009............................................................................. 17

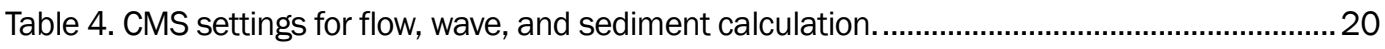

Table 5. Calculated morphology change and percent difference for August 2008..........................30

Table 6. Calculated morphology change and percent difference for January 2009........................30 


\section{Preface}

The data collection and numerical modeling studies presented in this report were authorized by the US Army Corps of Engineers (USACE) San Francisco District (SPN) to investigate the beneficial use of the dredge material and placement site near coast for the Federal Navigation Project at Noyo Harbor, CA. Peter Mull was the project study manager and technical coordinator. The technical work was performed by Dr. Lihwa Lin, Dr. Honghai Li, Mitch Brown, Lisa Andes, and Dr. Frank Wu. This study was partially supported by the Coastal Inlets Research Program (CIRP), funded by the US Army Corps of Engineers, Headquarters (HQUSACE). The CIRP is administered for Headquarters at the US Army Engineer Research and Development Center (ERDC), Coastal and Hydraulics Laboratory (CHL) of the U.S. Army Corps of Engineers. W. Jeff Lillycrop, CHL, is the Technical Director for the Navigation Program. Dr. Julie D. Rosati, CHL, is the CIRP Program Manager.

This work was performed at the CHL during the period October 2009 to September 2011 under the direction of Jeffrey P. Waters, Chief of the Coastal Engineering Branch, Rose M. Kress, Chief of the Navigation Division, Jose E. Sanchez, Deputy Director, and William D. Martin, Director of CHL.

COL Kevin J. Wilson was Commander and Executive Director and Dr. Jeffery P. Holland was Director of ERDC. 


\section{Unit Conversion Factors}

\begin{tabular}{|l|l|l|}
\hline Multiply & By & To Obtain \\
\hline cubic yards & 0.7646 & cubic meters \\
\hline feet & 0.3048 & meters \\
\hline inch & 0.3937 & centimeters \\
\hline miles (U.S. statute) & $1,609.3470$ & meters \\
\hline
\end{tabular}




\section{Introduction}

The USACE San Francisco District (SPN), and Coastal and Hydraulics Laboratory (CHL), U.S. Army Engineer Research and Development Center collaborated with the Noyo Harbor District and stakeholders to conduct a pilot study to investigate potential candidate site for nearshore placement of dredged sediments. The study includes field data collection and application of the most recent numerical modeling technology developed by the USACE Coastal Inlets Research Program (CIRP).

Noyo Harbor, located approximately 130 nautical miles northwest of San Francisco and some 145 nautical miles south-southeast of Crescent City, is the port and boat docking area for Fort Bragg in Mendocino County, CA. Figure 1 shows the location of Noyo and nearby Ten Mile River. It is a busy tourism coastal center vital to the economy of the local community. As the sole improved harbor between Bodega Bay and Humboldt Bay, the Harbor services commercial and sport fishing, and a US Coast Guard Search and Rescue Station. It provides for safe and secure access for commercial and recreational vessels and the safety of oceangoing vessels.

Dredging of the Noyo River Federal Navigation Project is necessary to provide access to Noyo Harbor for the US Coast Guard Search/Rescue Vessels and Recovery Operations and for mariners and fishing boats. Maintenance dredging of the Noyo River is the responsibility of the Army Corps of Engineers. The Noyo Harbor District is the lead agency working with SPN to manage the dredged material. The County of Mendocino is fully supportive of the USACE and Harbor Districts' efforts to develop the dredge material management plan and ensure continuation of this important aspect of the County's economy.

\subsection{Background}

There are more than two dozen littoral cells with distinct geographically divided sediment source compartments along the California's 1,100-mile coastline (Patsch and Griggs 2006). Each littoral cell incorporates a complete cycle of beach sediment supply, sand transport by the longshore current, and eventual permanent loss of sediment from the cell through either a submarine canyon, a coastal dune field, or in some cases, direct removal through sand mining. Littoral cells in California generally are 


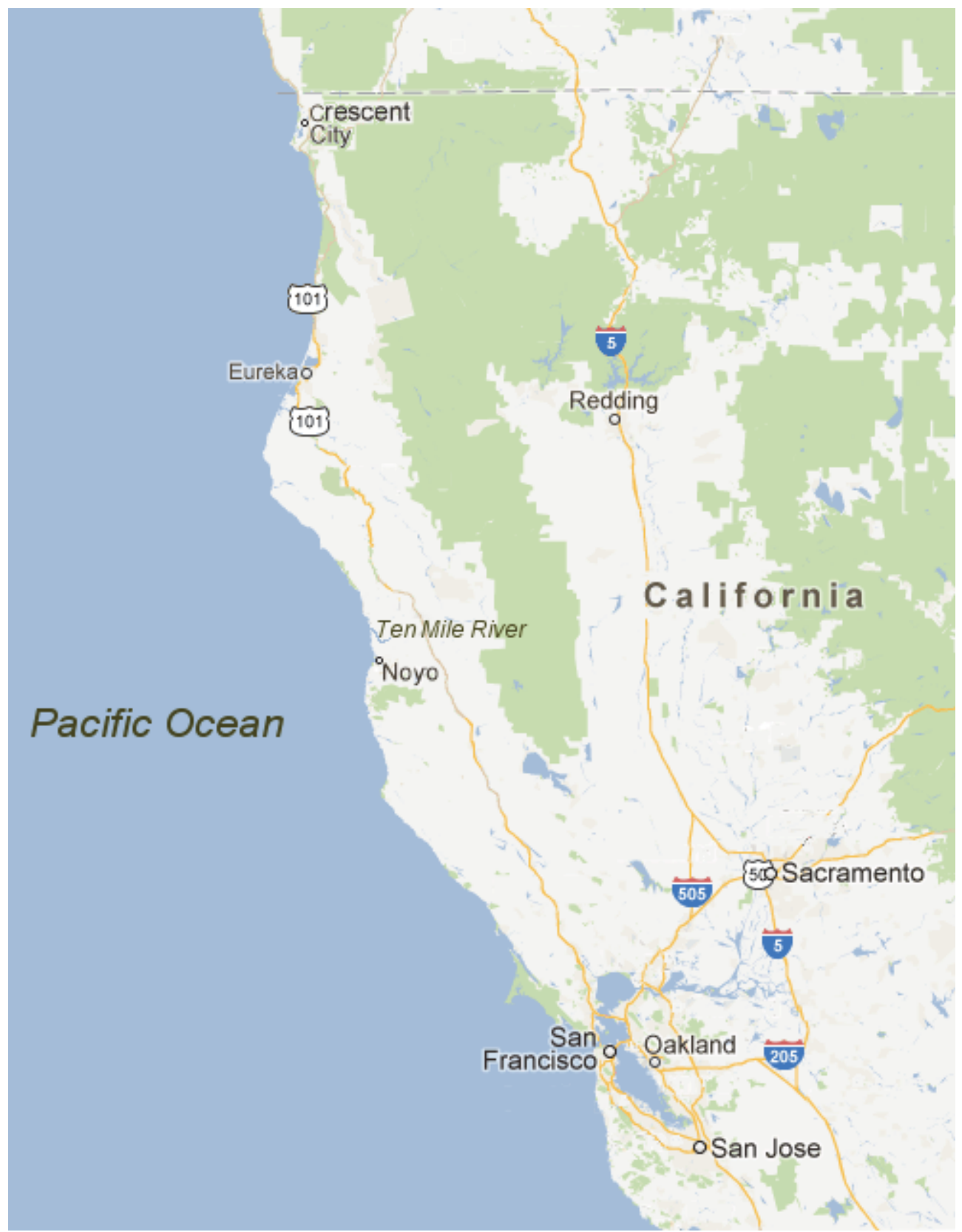

Figure 1. Location map of Noyo and Ten Mile River, CA.

distinct entities with little or no transport of sediment between cells. In a typical cell or beach compartment, littoral transport begins at a rocky headland or section of coast where the upcoast supply of sand or littoral drift is restricted or minimal. Sediments enter the littoral cell primarily from coastal streams and bluff erosion, and are transported alongshore under the influence of the prevailing wave conditions (Inman and Frautschy 1966). 
The movement of sand along the coastline under the influence of wind and waves has been observed for many years. The actual impacts and costs of interrupting or obstructing the littoral drift process have been painfully obvious along both the Atlantic and Pacific coasts of the United States since the 1930s. On the central and northern California coastline, a large gap exists in our present state of knowledge regarding littoral cell boundaries and production, transport, storage and loss of littoral sediment within these cells. The lack of a quantitative understanding of littoral cells and sand budgets is common along the California coast, mainly because of complicated spatial and temporal (seasonal and decadal) movement under the severe wave climate in the area.

Noyo Harbor is located inside the Ten Mile River Cell that encompasses a beach compartment between Westport and Ft. Bragg, Mendocino County. Ten Mile River is named for the fact that its mouth is ten miles (16 km) north of Noyo Bay. Ten Mile Beach, in MacKerricher State Park, extends approximately five miles southward from the mouth of Ten Mile River, including approximately 1,300 acres $\left(5.3 \mathrm{~km}^{2}\right)$ of what has been called California's most pristine stretch of sand dunes (Figures 1 and 2).

The existing Noyo Harbor and River channel was authorized by the River and Harbor Act of 1930 and construction was completed in 1961. It consists of a jettied entrance at the river mouth. The design is a 10- $\mathrm{ft}$ deep, $100-\mathrm{ft}$ wide entrance channel and a $10-\mathrm{ft}$ deep, $150-\mathrm{ft}$ wide river channel extending upstream for 0.6 mile.

Historically, dredging of Noyo River and Harbor entrance was conducted on an annual basis. Because of the lack of funding, dredging was halted in 2000 and resumed as an emergency maintenance in November 2006. The navigation channel has since been dredged approximately on a two-year cycle. The dredged material has been placed in a landfill, and the disposal site issue has been and continues to be a major concern as capacity of the disposal site is projected to reach its maximum limit within five to 10 years.

The heavy rains of late December 2005 and early January 2006 caused heavy silt deposits in the navigable channel, making it impassible during certain low tides. The emergency dredging of Noyo River in 2006 had only maintained a channel depth of $8.7 \mathrm{ft}$ not the design depth of $10 \mathrm{ft}$. The impact was felt not only by the local commercial and recreational fisherman, but also by support businesses such as the fuel dock, ice house and 


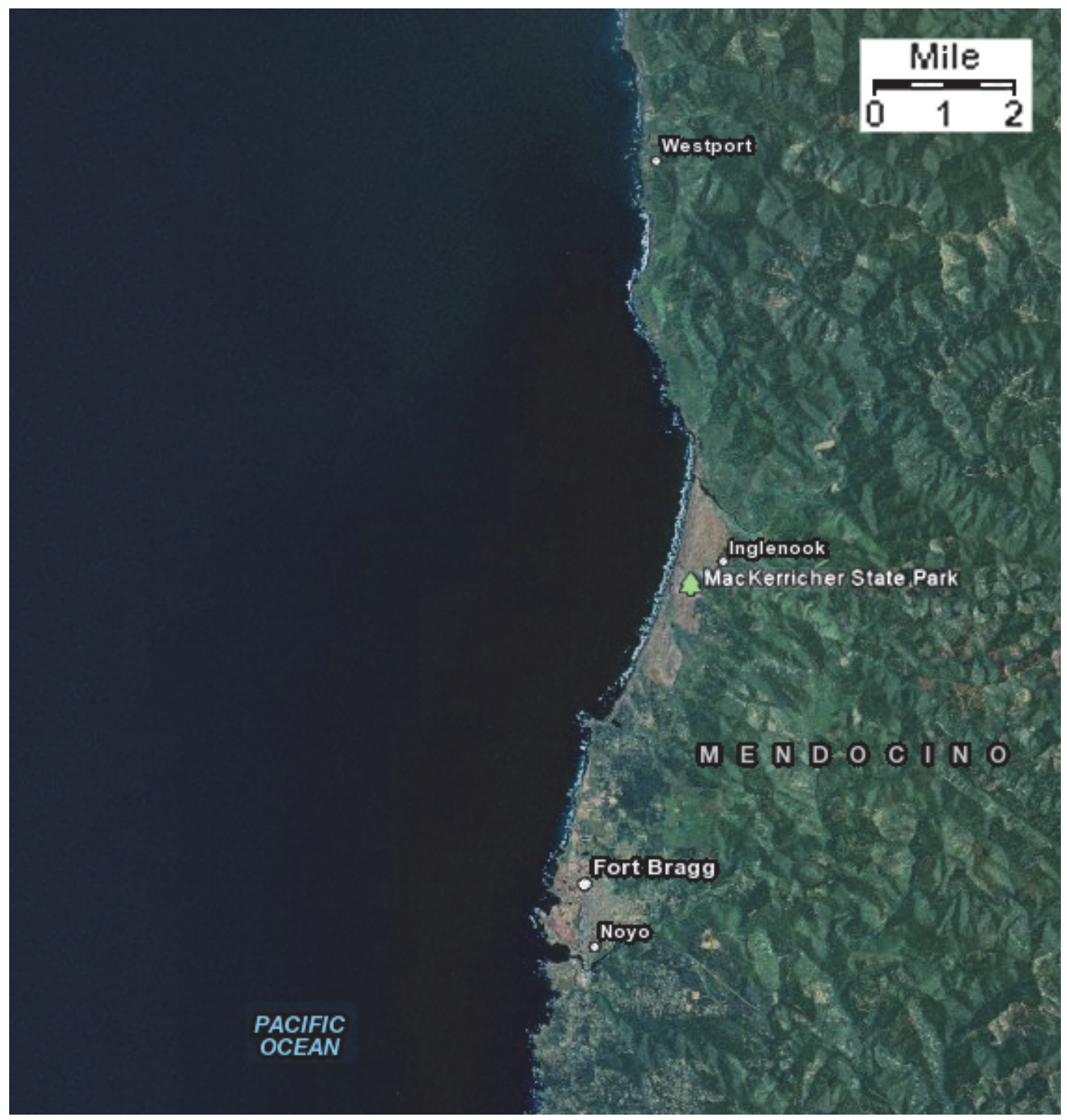

Figure 2. Noyo, Fort Bragg, and MacKerricher State Park, Mendocino County, CA.

charter boats. One of the main concerns was the impact to the local Coast Guard Search and Rescue Operations unit who were unable to respond during shallow waters at low tides.

The Water Resources Development Act of 1996, Section 217 Provisions approved cost sharing for dredged material disposal facilities associated with maintenance of Federal Navigation Project. In the past, dredged material was placed entirely in the landfill site. Because the dredge material site is at capacity, the Noyo Harbor District and SPN are considering beneficial use of dredged sediment and a Dredged Material Management Plan (DMMP). This pilot study was required before a demonstration project and DMMP could be initiated. 


\subsection{Objectives}

The SPN identified a need to investigate the potential nearshore site for dredged material placement, and proposed to employ a set of modeling tools for the present study.

The objectives of the study were:

1. Collaborate with local stakeholders to identify candidate sites for nearshore placement.

2. Determine the sedimentation processes during the release and settlement of dredged material at the placement site.

3. Quantify sediment transport and morphology change at the dredged material placement site over days to weeks.

4. Assess changes in the nearshore environment caused by the dredged material placement under different wave, tide, and wind conditions.

Based on available resources, the study objectives were judged to be best met through numerical simulation and evaluation of waves, tide, current, and sediment transport.

\subsection{Method}

To achieve the study objectives, the USACE Short-Term FATE model (STFATE) and Coastal Modeling System (CMS) were applied to determine the sediment fate and movement during and after the dredged material placement. The STFATE (Johnson 1990) simulates the areal distribution of dredged material in open water after it has passed through the water column on an individual release of the barge load. The CMS (Demirbilek and Rosati 2011; Lin et al. 2008, 2011; Lin and Demirbilek 2010) calculates wave transformation and wave-induced currents, water level change by tide, wind, and waves, interacting waves and currents, and sediment transport and morphology change. The CMS implicit flow model is used in this study to calculate both short- and intermediate-term changes to the dredged material placement site. This study served to improve the interface for coupling the CMS and PTM. The improved modeling technology will be used in other Corps projects.

An intensive field data collection study is presently underway (Spring 2012) including nearshore bathymetry, current, wave, and suspended sediment measurements to support the next phase of the study. Final model simula- 
tions will be conducted using the updated bathymetry surveys and with newly measured flow, wave, and sediment property data. Because recent bathymetry data were not available to accurately represent the nearshore, the present numerical modeling should be considered preliminary.

The approach taken for the CMS modeling was as follows:

1. Assemble and review relevant historical data on bathymetry, tide, waves, wind, and sediment.

2. Select one summer month and one winter month for model simulations. The former is considered a non-storm period. The latter is identified as a typical winter that should include multiple storms.

3. Force the CMS with wind, waves and water surface elevation (wse) data to evaluate calculations representing pre- and post-placement of the dredged material.

4. Analyze and compare model simulation results for existing conditions and different placement locations.

\subsection{Scope of report}

This study proceeded by evaluating hydrodynamic and morphology change associated with different dredged material placement sites. Chapter 2 describes the data used to force the CMS model. Chapter 3 provides information on the CMS model framework, setup, and alternatives evaluated. Chapter 4 presents model results for two selected simulation periods, and Chapter 5 presents conclusions of the study. 


\section{Data Assembly}

\subsection{Coastline and bathymetry}

Coastline information for Noyo Bay along the north central coast of the California was extracted for this study from a geo-referenced image file downloaded from Google Earth 5.0 (http://earth.google.com). The coastline digital data are available from the National Geophysical Data Center website (http://rimmer.ngdc.noaa.gov).

Bathymetry data for the nearshore area surrounding Noyo Bay were obtained from the NOAA Coastal Services Center Lidar (http://www.csc.noaa.gov/ data.html) and California Seafloor Mapping Program (CSMP, http://walrus.wr.usgs. gov/mapping/csmp). The offshore bathymetry data were obtained from GEOphysical DAta System (GEODAS) database, which has been developed and managed by the National Geophysical Data Center (http://www.ngdc.noaa.gov/ $\mathrm{mgg} /$ bathymetry/relief.html). The land elevation data were downloaded from USGS Geographical Digital Elevation models (DEM, http://edc2.usgs.gov/geodata/ index.php). Figure 3 shows the depth contours, relative to mean sea level (MSL) from the combination of the above datasets for the study domain. Figure 4 shows the Noyo Bay bathymetry with the aerial photo.

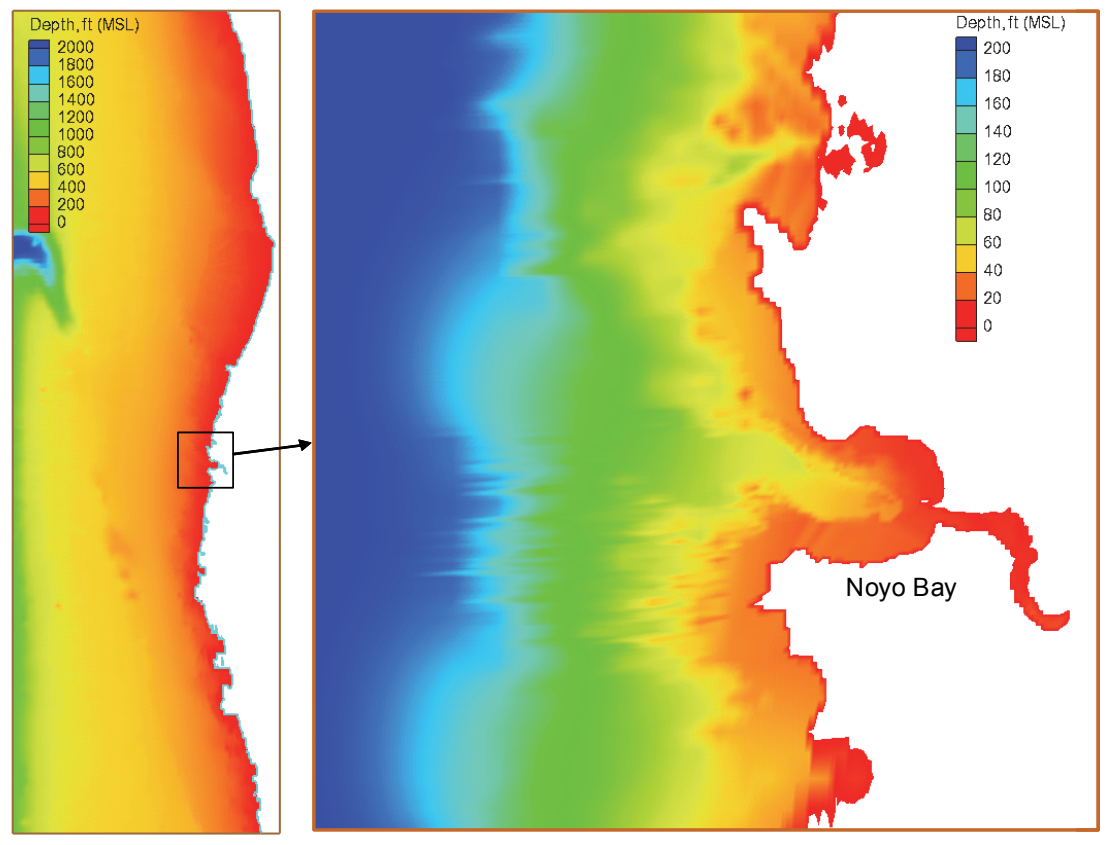

Figure 3. Noyo Bay and coast bathymetry contours in ft related to MSL. 


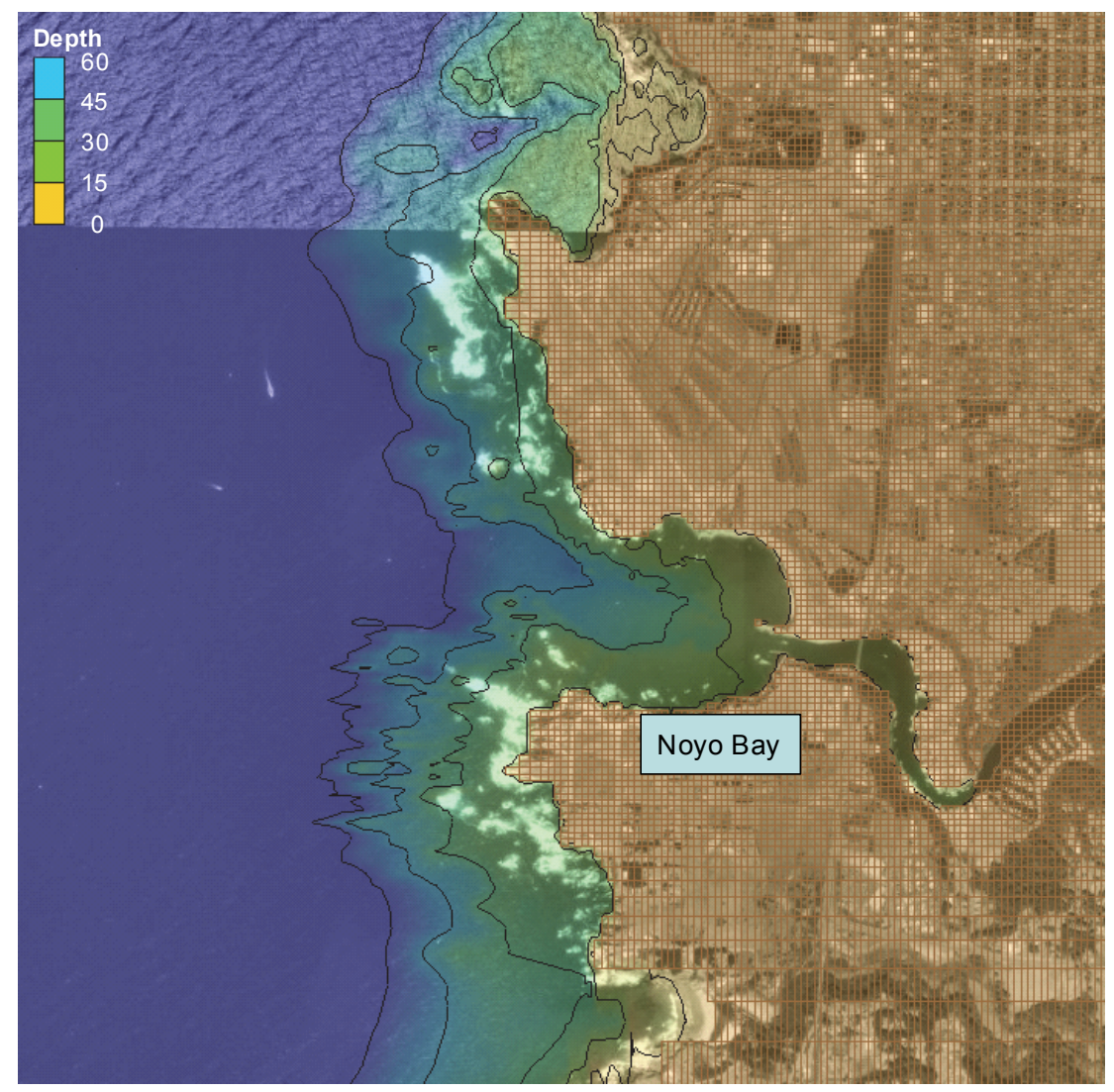

Figure 4. Noyo Bay bathymetry (depth contour increment in $15 \mathrm{ft}$ ) and aerial photo.

\subsection{Wind and wave data}

Directional wave data are available from the National Data Buoy Center (NDBC, http://www.ndbc.noaa.gov) Buoy 46022 and Coastal Data Information Program (CDIP, http://cdip.ucsd.edu) Buoy 46213. NDBC Buoy 46014, located offshore Noyo Bay, collects non-directional wave data. Ocean surface wind data are available from NDBC Buoys 46014 and 46022. Coastal wind data are available from NOAA Stations ANVC1 (Arena Cove) and PTAC1 (Point Arena). Figures 5 and 6 show the wind and wave roses, respectively, at the corresponding buoy and coastal stations based on 2008 data. Figure 7 shows the monthly mean wave height at Buoys 46014, 46022, and 46213 for 2008. The monthly mean wave height offshore Noyo Harbor at Buoy 46213 can exceed $11.5 \mathrm{ft}(3.5 \mathrm{~m})$ in the winter and $6.6 \mathrm{ft}(2.0 \mathrm{~m})$ in the summer.

\subsection{Water surface elevation}

Water surface elevation data are available from NOAA Station 9416841 (Arena Cove, ANVC1, http://tidesandcurrents.noaa.gov). Figure 8 shows the hourly water surface elevations for April and December 2008 from NOAA Station 


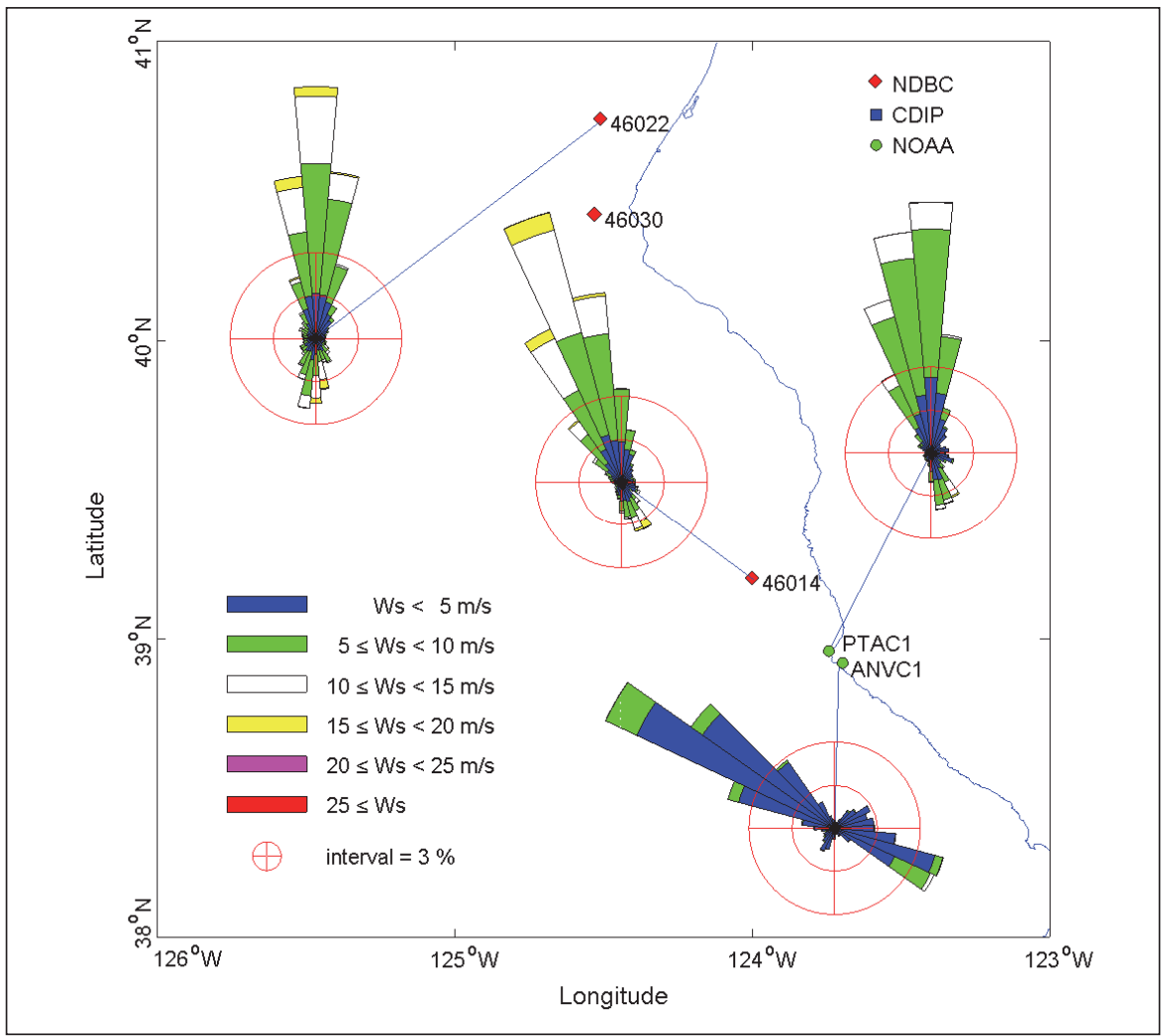

Figure 5. Wind roses based on 2008 data.

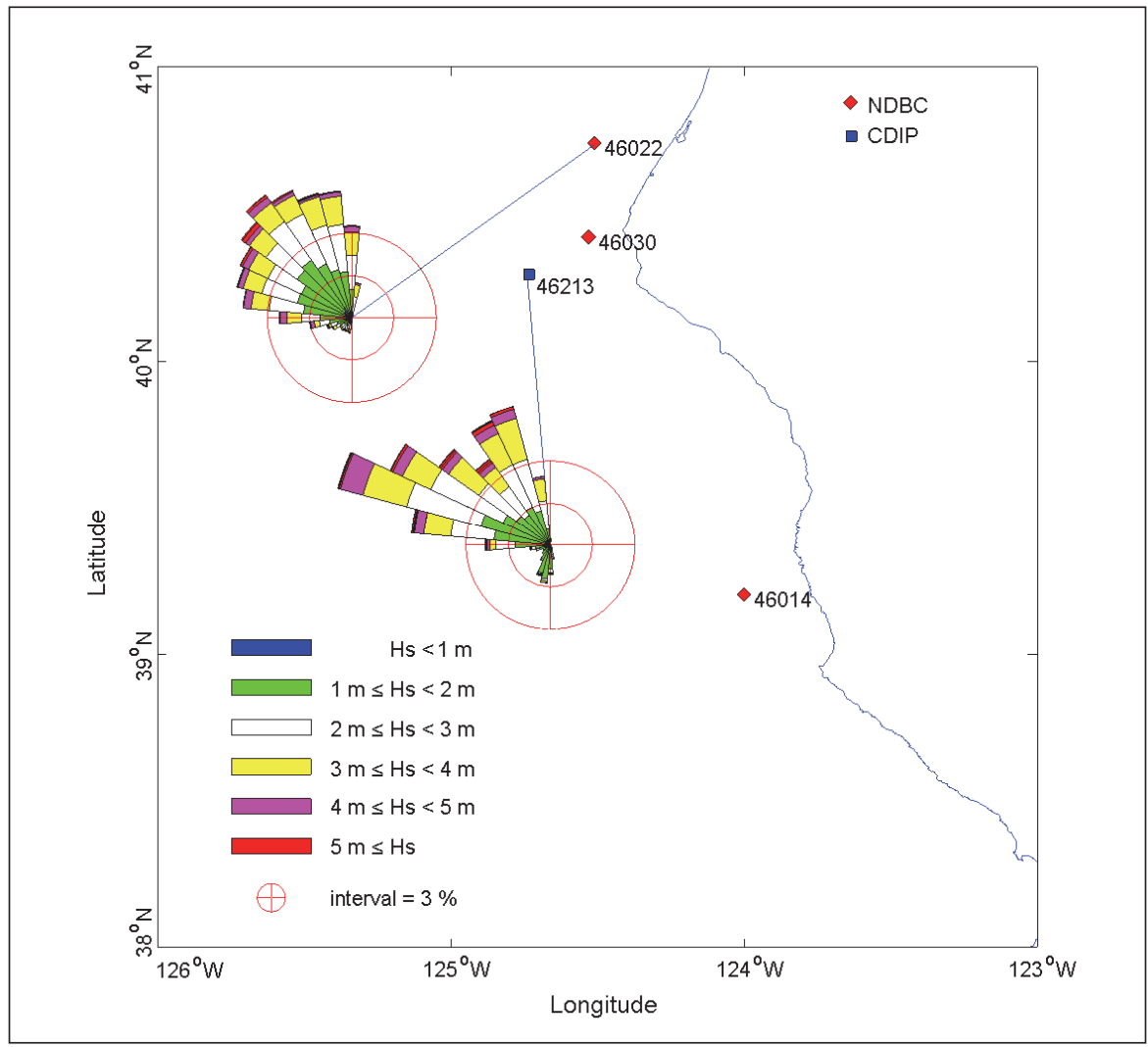

Figure 6. Wave roses based on 2008 data. 


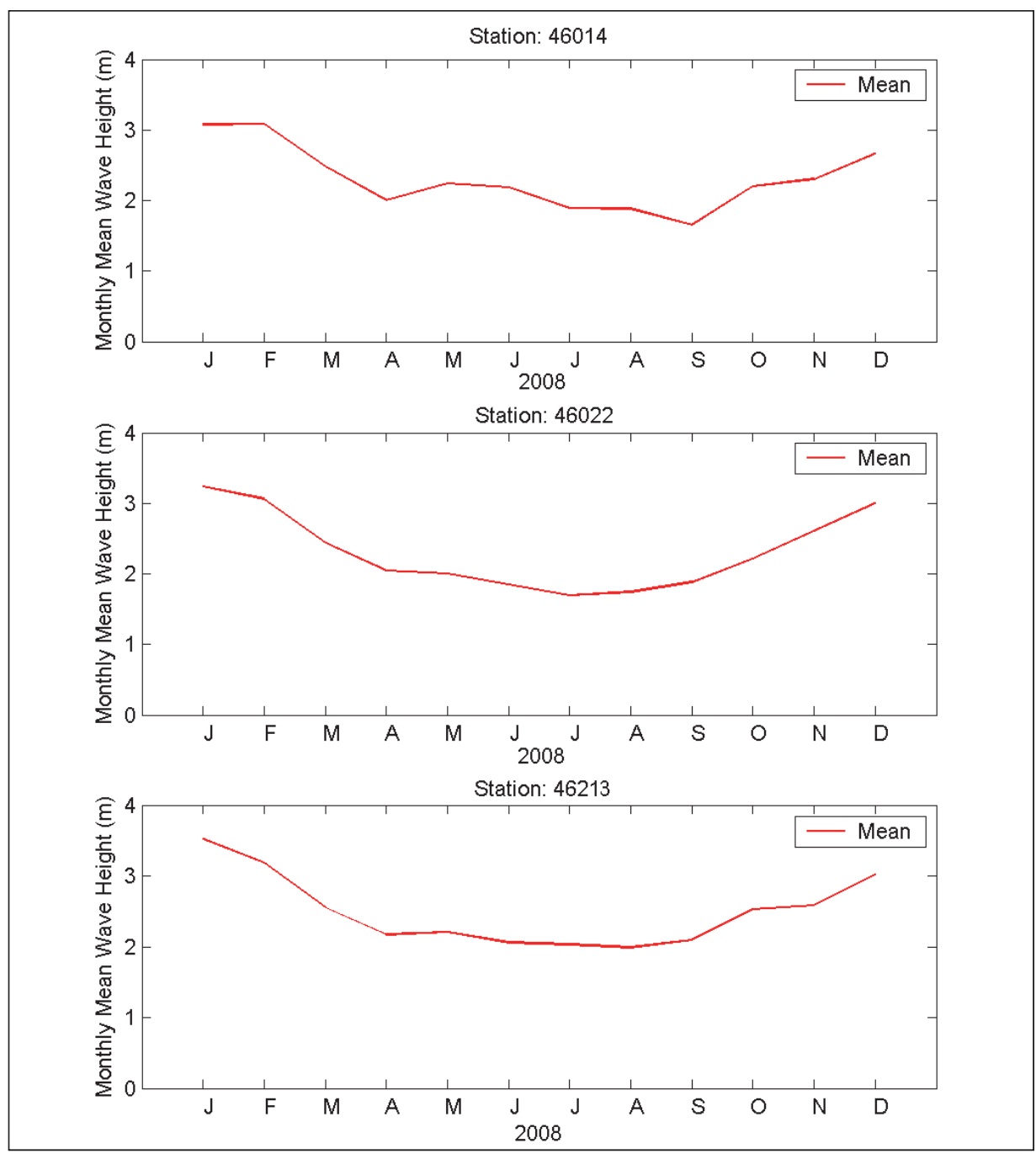

Figure 7. Monthly mean wave height at Buoys 46014, 46022, and 46213 for 2008.

9416841 and 9418767 (North Spit, Humboldt Bay, approximately 95 miles north of Noyo Harbor). The water level data indicate a mixed semi-diurnal tidal regime surrounding northern California coast. The mean tidal range (mean high water - mean low water) is $4 \mathrm{ft}(1.2 \mathrm{~m})$ and the maximum tidal range (mean higher high water - mean lower low water) at Arena Cove is $5.9 \mathrm{ft}(1.8 \mathrm{~m})$. Table 1 lists the NDBC, CDIP, and NOAA stations of interest and their location information.

\subsection{Sediment characteristics}

A recent sediment study of the Noyo River navigational channel in 2009 conducted by Weston Solutions, Inc. indicated the dredge material was nearly all sand with small percentages of mixed gravel, silt and clay (Table 2). 


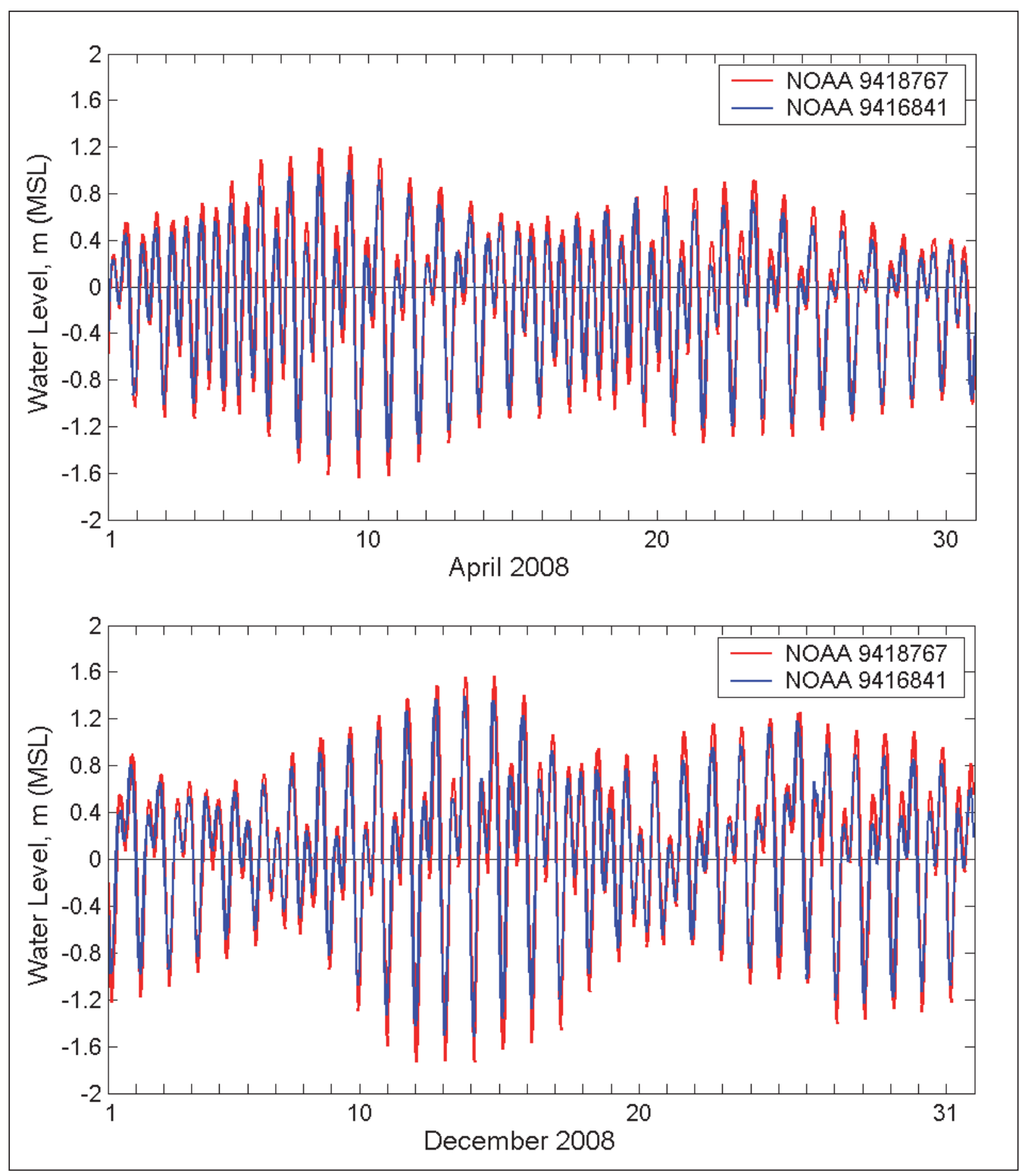

Figure 8. Time series of water levels at NOAA Stations 9416841 and 9418767 for April and December 2008.

Table 1. NDBC, CDIP, and NOAA station locations.

\begin{tabular}{|c|c|c|c|}
\hline Station & Latitude & Longitude & Nominal depth $(\mathrm{m})$ \\
\hline NDBC 46014 & $39 \circ 13^{\prime} 12^{\prime \prime} \mathrm{N}$ & $123^{\circ} 58^{\prime} 12^{\prime \prime} \mathrm{W}$ & 275 \\
\hline NDBC 46022 & $40^{\circ} 44^{\prime} 24^{\prime \prime} \mathrm{N}$ & $124^{\circ} 30^{\prime} 36^{\prime \prime} \mathrm{W}$ & 610 \\
\hline CDIP 46213 & $40^{\circ} 17^{\prime} 33^{\prime \prime} \mathrm{N}$ & $124^{\circ} 44^{\prime} 21^{\prime \prime} \mathrm{W}$ & 325 \\
\hline NOAA PTAC1 & $38^{\circ} 57^{\prime} 36^{\prime \prime} \mathrm{N}$ & $123^{\circ} 44^{\prime} 24^{\prime \prime} \mathrm{W}$ & N/A \\
\hline $\begin{array}{l}\text { NOAA 9416841, } \\
\text { ANVC1 }\end{array}$ & $38^{\circ} 54^{\prime} 47^{\prime \prime} \mathrm{N}$ & $123^{\circ} 42^{\prime} 29^{\prime \prime} \mathrm{W}$ & N/A \\
\hline NOAA 9418767 & $40^{\circ} 46^{\prime} 01^{\prime \prime} \mathrm{N}$ & $124^{\circ} 13^{\prime} 01^{\prime \prime} \mathrm{W}$ & N/A \\
\hline
\end{tabular}


Table 2. Grain grain sizes of sediment samples taken in Noyo Harbor channels (Weston Solutions, Inc. 2009).

\begin{tabular}{|l|l|}
\hline Sediment & Grain Fractions (\%) \\
\hline Gravel & 1.0 \\
\hline Sand & 89.8 \\
\hline Silt & 6.1 \\
\hline Clay & 3.1 \\
\hline
\end{tabular}




\section{Modeling Strategy}

The CMS was applied for simulating waves, circulation, and sediment transport in the vicinity of Noyo Harbor. The hydrodynamic and wave models, CMS-Flow and CMS-Wave, were coupled and operated through the Steering Module within the Surface-water Modeling System (SMS, Zundel 2006), which interact dynamically in simulating sediment transport and morphology change (Demirbilek and Rosati 2011; Lin et al. 2008, 2011). The particle tracking model, CMS-PTM (Demirbilek et al. 2008), was applied to simulate the fine sediment movement during and after the release of the dredged material by the barge at the placement site.

\subsection{Model description}

CMS-Flow is a three-dimensional (3-D) finite-volume model that solves the mass conservation and shallow-water momentum equations of water motion. The model can run in a two-dimensional (2-D) mode based on the depth-integrated continuity equation. The wave radiation stress and wave information entering the flow and sediment transport formulas are supplied to CMS-Flow through coupling with CMS-Wave. Calculated currents and water level change are returned to the wave model to increase the accuracy of the wave transformation predictions.

CMS-Flow is forced by changes in offshore water surface elevation (e.g., from tide), wind, river discharge, and wave radiation stress (Demirbilek and Rosati 2011). Physical processes pertinent to the present study calculated by CMS-Flow are current, water surface elevation, sediment transport, morphology change, and representation of non-erodible bottom (reef). Additional capabilities include flooding and drying, space-varying bottom-friction, salinity transport, efficient grid storage in memory, and hot-start options.

CMS-Wave is a two-dimensional (2-D), full-plane wave spectral transformation model implemented in CMS (Lin et al. 2012). It is a phase-averaged model which computes changes in the wave energy to calculate wave properties. CMS-Wave contains theoretically derived approximations for wave diffraction, reflection, and wave-current interaction, and therefore, is appropriate for conducting wave simulations at coastal inlets with jetties 
and breakwaters. It employs a forward-marching, finite-difference, steadystate (time-independent) Eulerian method to solve the wave action conservation equation. The model can run faster in half-plane mode, so primary waves can propagate only from the seaward boundary toward shore. If the seaward reflection option is activated, CMS-Wave performs backward-marching for seaward reflection after the forward-marching calculation is completed.

PTM is a particle tracking model capable of introducing and following the trajectory of discrete particles in the flow field (Demirbilek et al. 2008). It computes the paths of sediment particles using the Lagrangian method through a geometric domain as the particles interact with the environmental forcing. The sediment particle can be of either cohesive (silt, clay) or non-cohesive (sand). The computational environment includes the hydrodynamic flow, wave conditions, sediment property, and land boundary. Therefore, water surface elevations and currents calculated by CMS-Flow and wave information by CMS-Wave drive the PTM computations in the same CMS domain. The SMS includes tools to generate the necessary information to define the PTM environment, such as sediment release method and sediment properties.

\subsection{Model domain}

The Noyo River empties into Noyo Cove, which is approximately $1,800 \mathrm{ft}$ (550 m) wide, north to south, and 2,000 ft (610 m) long, east to west. Noyo Harbor, constructed in 1961, consists of dual jetties at the river mouth; a 10-ft (3-m) deep, 100- $\mathrm{ft}(30.5-\mathrm{m})$ wide entrance channel; and a 10-ft (3-m) deep, 150-ft (45.7-m) wide river channel extending upstream about $1 \mathrm{~km}$. The shoreline of the area consists of broken irregular cliffs about 40 to $80 \mathrm{ft}$ ( 12 to $24 \mathrm{~m}$ ) high with numerous rocks extending several hundred meters offshore. Aerial photographs of the area are shown in Figure 2 and the background of Figure 4 .

In the application of CMS to Noyo Harbor and vicinity, a variable-resolution grid system was created to discretize the entire harbor, bay, and the offshore region. The model domain extends approximately 35.4 miles $(57 \mathrm{~km})$ alongshore and 11.1 miles $(18 \mathrm{~km})$ offshore, and the offshore boundary of the domain reaches to the 1,000-ft (300-m) isobath. Figure 3 shows the CMS domain, a rectangular grid consisting of $273 \times 747$ cells and bathymetry of Noyo Bay, and adjoining nearshore and continental shelf. The grid permits much finer grid resolution to $65 \mathrm{ft} \times 65 \mathrm{ft}(20 \mathrm{~m} \mathrm{x} 20 \mathrm{~m})$ in areas of 
high interest such as the near the harbor, and coarser resolution to $650 \mathrm{ft} x$ $650 \mathrm{ft}(200 \mathrm{~m} \times 200 \mathrm{~m})$ at the ocean boundary.

\subsection{Simulation period and model forcing}

The model simulations were conducted for August 2008 and January 2009 representing typical summer and mild winter months, respectively. Figure 9 shows the time series of wave and wind data collected at Buoys 46014, 46022, and 46213 for August 2008. Figure 10 shows the hourly wave and wind data at Buoys 46014 and 46213 for January 2009. Table 3 presents the corresponding buoy mean and maximum significant wave heights of August 2008 and January 2009. The wave data collected at Buoy 46213 show larger mean and maximum significant heights than at the other two buoys in August 2008 and January 2009.

In the present study, the directional wave spectra collected at Buoy 46213 were applied as input for the wave model simulation. The wind data collected at Buoy 46014 were used as input for both wave and flow simulations. Wind magnitude is stronger in January 2009 than in August 2008. The wind direction at Buoy 46014 is predominantly from northnorthwest and is parallel to the local coastline. This predominant wind direction is consistent to the wind rose diagram shown in Figure 5.

The local water level data from NOAA Station 9416841 were used as the boundary condition for coupled flow and wave models. Figure 11 shows the time series of hourly water levels collected at NOAA 9416841 in August 2008 and January 2009.

\subsection{Potential placement sites}

Littoral drift along the Mendocino County coast is directed from north to south as a result of the majority of ocean waves approaching between the north and west directions. The mean current from the continental shelf and slope off the central west coast is mainly southward driven by the persistent northern wind in the region. For a beneficial use of the clean dredge sediment from Noyo River, the ideal locations for nearshore placement were considered north of Noyo Bay and south of Ten Mile River.

Figure 12 shows three potential dredged material placement sites, located approximately two, five, and eight miles north of Noyo Bay. In the present study, only Sites 1 and 2, two and five miles north of Noyo, respectively, were 

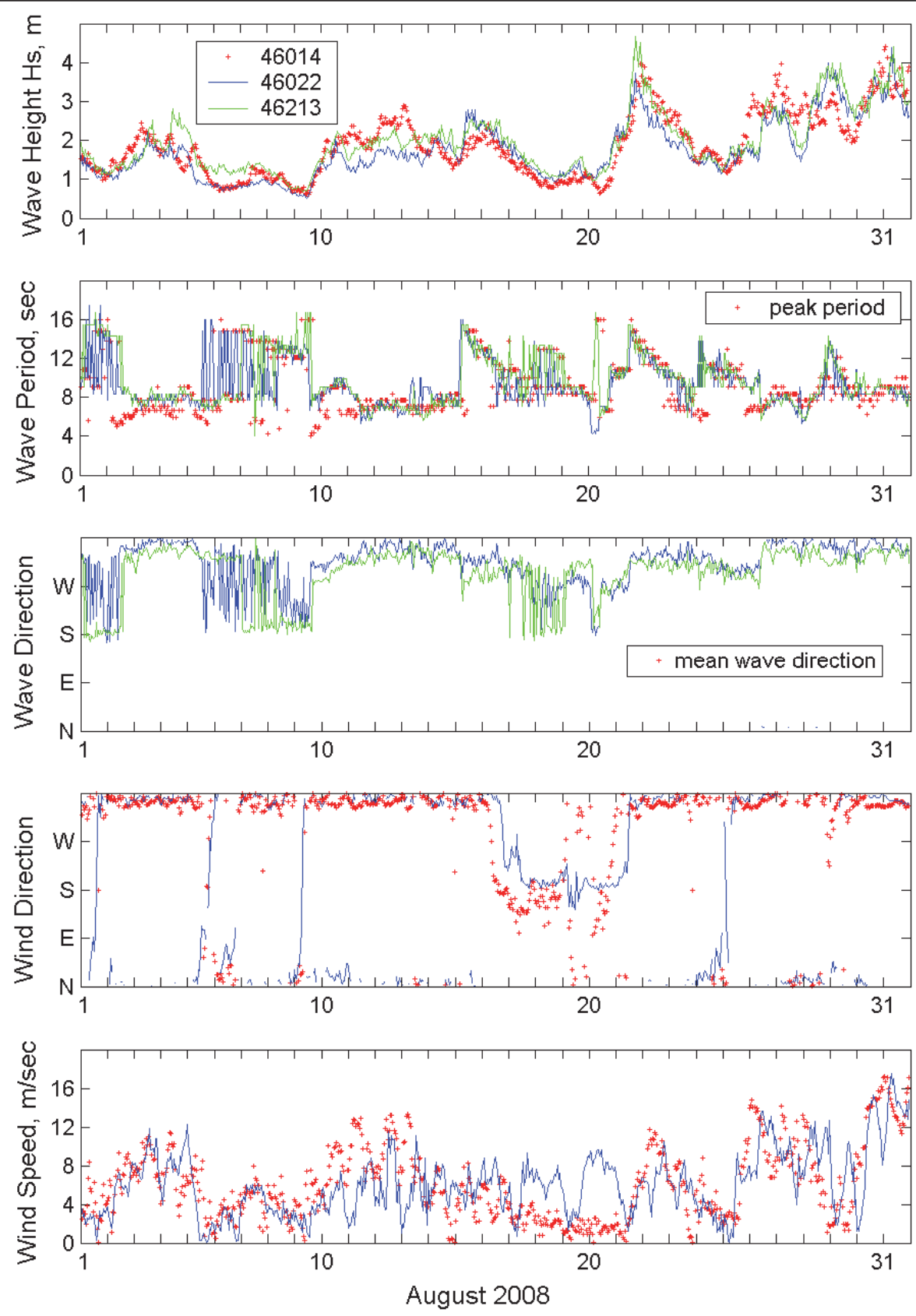

Figure 9. Significant wave height, peak wave period, mean wave direction, wind speed, and wind direction from Buoys 46014, 46022, and 46213, August 2008. 


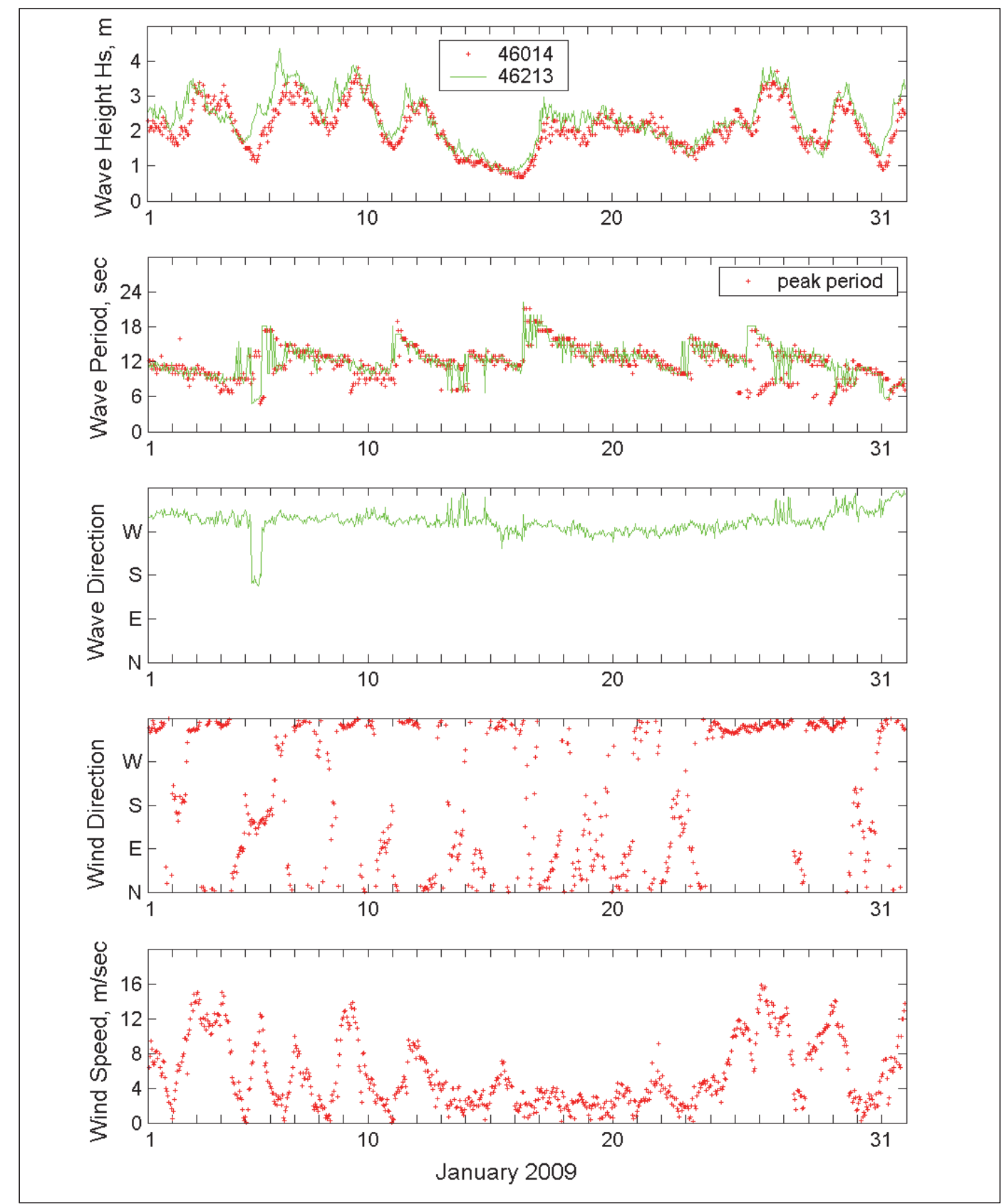

Figure 10. Significant wave height, peak wave period, mean wave direction, wind speed, and wind direction from Buoys 46014 and 46213, January 2009.

Table 3. Mean and maximum significant wave heights from Buoys 46014, 46022, and 46213 for August 2008 and January 2009.

\begin{tabular}{|l|l|l|l|l|}
\hline \multirow{2}{*}{ Station } & \multicolumn{2}{|c|}{ Significant wave height, August 2008 } & \multicolumn{2}{l|}{ Significant wave height, January 2009 } \\
\cline { 2 - 5 } & Mean $(\mathrm{m})$ & Maximum $(\mathrm{m})$ & Mean $(\mathrm{m})$ & Maximum $(\mathrm{m})$ \\
\hline 46014 & 1.9 & 4.4 & 2.1 & 3.8 \\
\hline 46022 & 1.8 & 4.4 & N/A & N/A \\
\hline 46213 & 2.0 & 4.7 & 2.3 & 4.4 \\
\hline
\end{tabular}




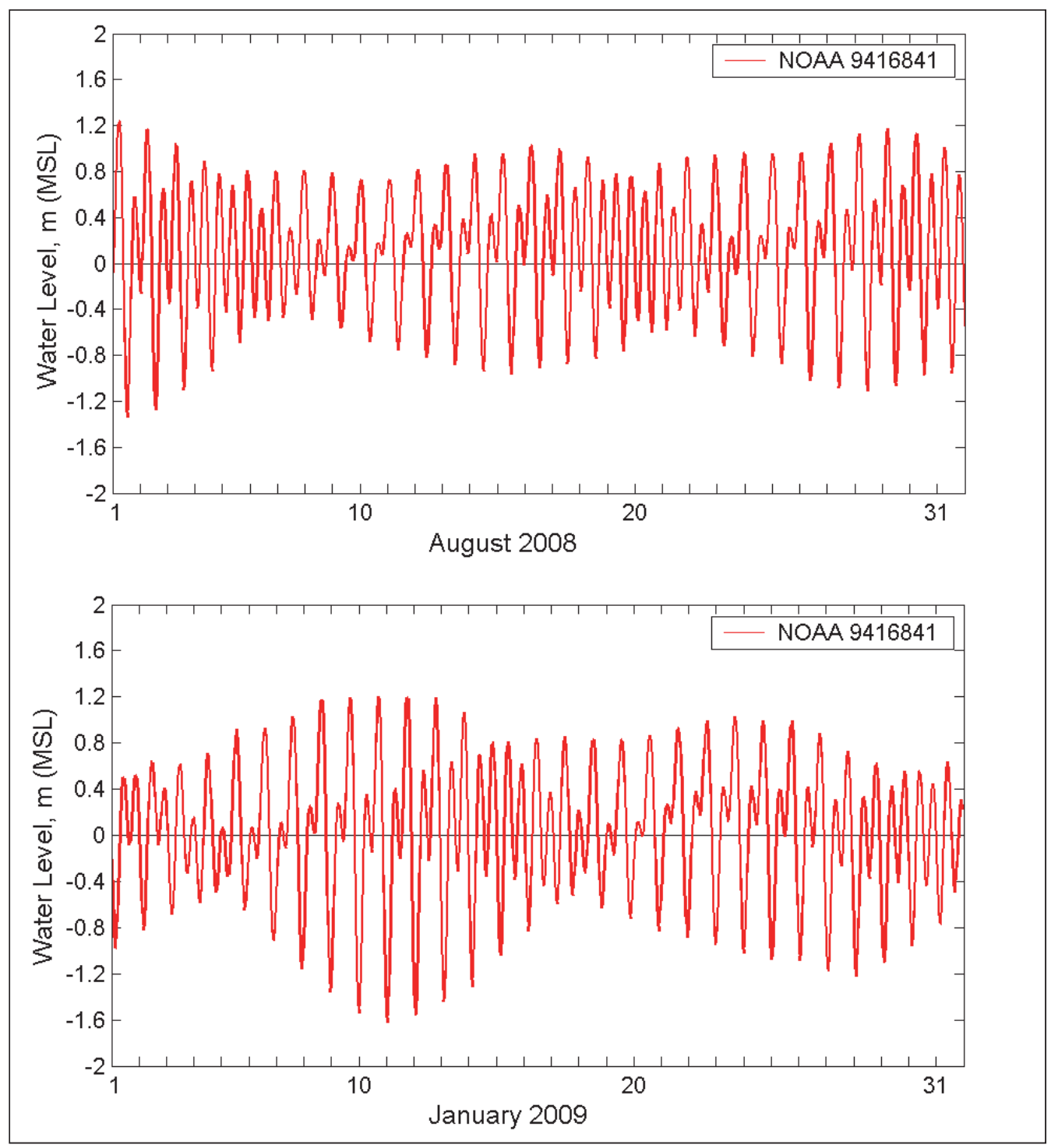

Figure 11. Time series of water levels at NOAA Stations 9416841 for August 2008 and January 2009 used as the boundary condition for CMS.

simulated in CMS because the most northern site at eight miles north of Noyo is geologically more sensitive to the beach and dunes in MacKerricher State Park and economically more expensive to barge the dredge material from Noyo River. Figure 13 delineates the area of the two potential sites, with the footprint each site of approximately $700 \mathrm{ft} \times 3,700 \mathrm{ft}(210 \mathrm{~m} \times 1,120 \mathrm{~m})$, located between the 40- and 60-ft (12- and 18-m) contours.

\subsection{Model simulation settings}

The CMS-Flow 2-D implicit-scheme version was used for hydrodynamics and sediment transport modeling, and coupled with the CMS-Wave. Both tide and wind forcing were considered in the simulations for August 2008 


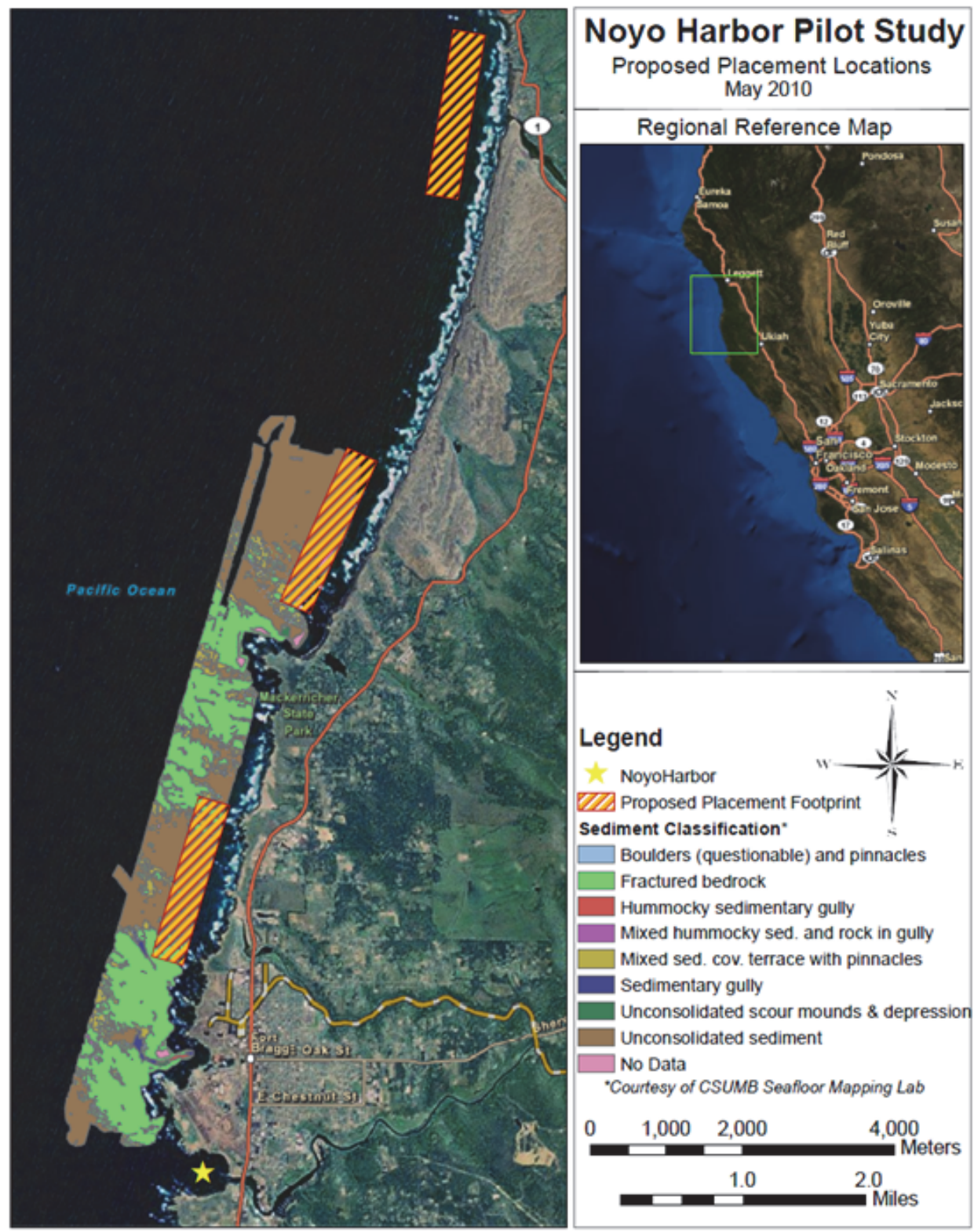

Figure 12. Three potential placement sites for dredge material.

and January 2009. A constant grain size of $0.18 \mathrm{~mm}$ was specified for the sediment simulation. Because bedrock information was not available, a hard bottom beneath an initial 4-inch $(10-\mathrm{cm})$ sediment layer was specified between the $\mathrm{o}-$ and 40-ft (12-m) depth contours. The primary CMS model parameters used in these simulations are listed in Table 4. The hydrodynamic and wave results from CMS were used as input to the PTM for the standard particle tracking calculations. 


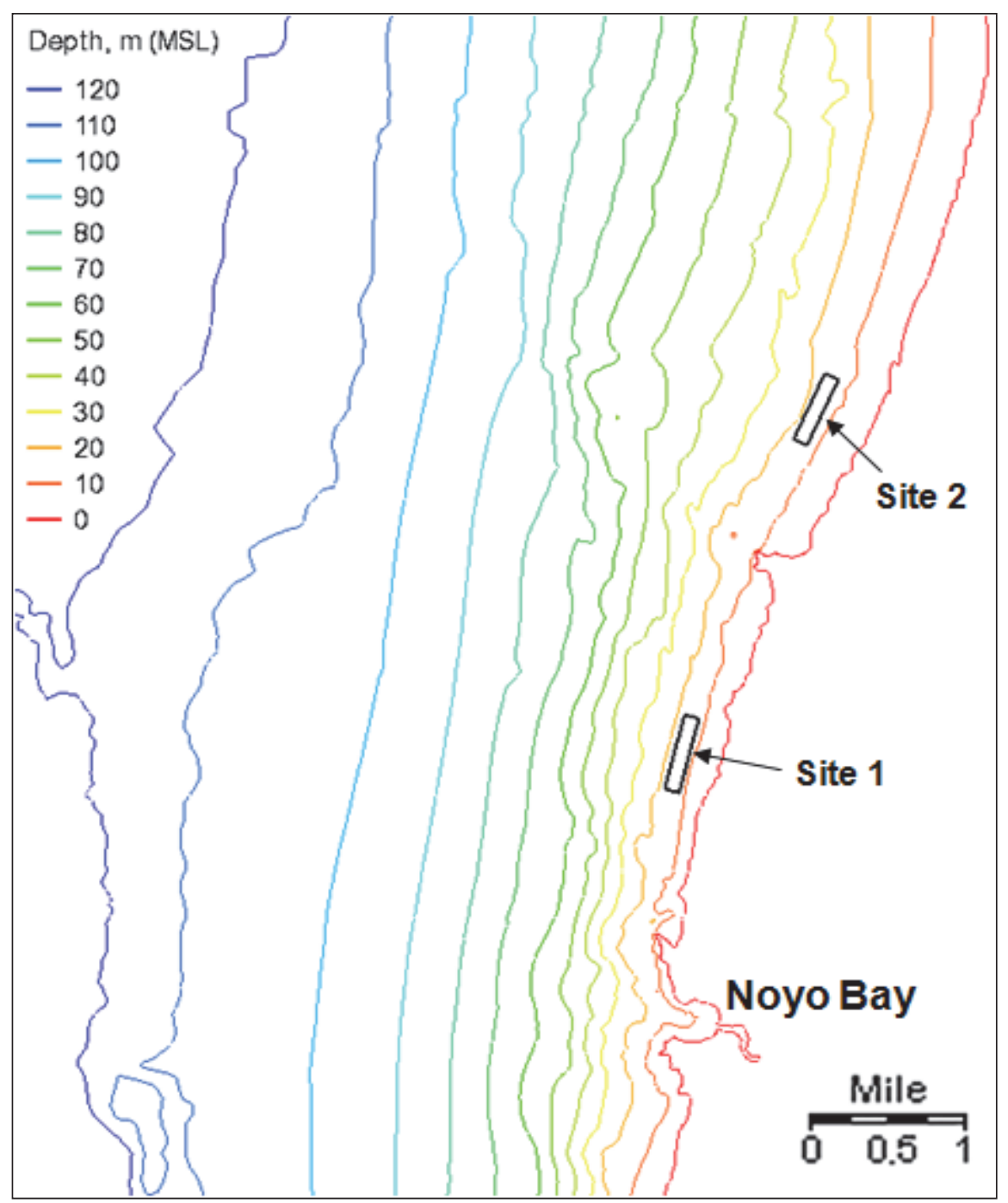

Figure 13. Potential sites 1 and 2 for CMS simulation.

Table 4. CMS settings for flow, wave, and sediment calculation.

\begin{tabular}{|l|l|}
\hline Parameter & Value \\
\hline Manning's $n$ & 0.025 \\
\hline Advection & Included \\
\hline Wetting and Drying & Included (minimum wet depth is $0.1 \mathrm{~m}$ ) \\
\hline Wave Spectral Energy & Half Plane \\
\hline Wave Breaking & Extended Goda formula (Goda 1973) \\
\hline Diffraction Intensity & 4.0 \\
\hline$D_{50}(\mathrm{~mm})$ & 0.18 \\
\hline Sediment Density $\left(\mathrm{kg} / \mathrm{m}^{3}\right)$ & $2,650.0$ \\
\hline Sediment Porosity & 0.4 \\
\hline Hard Bottom & Partial (0 to 40-ft depth), with an initial 4-inch thick sediment layer \\
\hline Transport Equation & Non-equilibrium \\
\hline
\end{tabular}




\section{Results and Discussion}

The CMS simulations were conducted to calculate the sediment transport using tide, wind, and wave forcing for August 2008 and January 2009, representing one normal summer month and one mild winter month, respectively. The simulations included the existing configuration, and two nearshore potential sites north of Noyo bay for the beneficial use of clean dredge material placement. The footprint of each disposal site was approximately of $700 \mathrm{ft} \times 3,700 \mathrm{ft}(210 \mathrm{~m} \times 1,120 \mathrm{~m})$ located at depth contours between 40- and 60-ft (12- and 18-m) (Figure 13). A constant sediment volume of 46,000 cu yd (35,000 cubic meters) was specified for each placement site to simulate the nearshore placement. This sediment volume presented a uniform 6 -inch $\left(15^{-} \mathrm{cm}\right)$ sediment layer above the existing seabed inside the rectangular placement area. Numerical simulations were conducted for tide and wind input with and without the wave forcing to investigate the sediment transport patterns at the placement sites.

\subsection{August 2008 simulation}

Figures 14 and 15 show snapshots of calculated sediment concentration transport to south from the placement Sites 1 and 2, respectively, without the wave forcing for August 2008. This sediment concentration movement from Sites 1 and 2 mainly follows the mean current toward the south as a result of persisting northern wind in the region. Figure 16 shows the calculated strong sediment transport pattern from Site 1 and 2 with wave forcing in addition to tide and wind input for August 2008. With the wave forcing included, the sediment concentration nearshore is much greater than at Site 1 and 2 owing to strong wave breaking in the surf zone, indicating that the sediment transport at Site 1 and 2 is negligibly small as compared to the greater sediment movement by waves along the shoreline.

Figures 17 and 18 show the calculated sediment accretion and erosion pattern at Sites 1 and 2, respectively, without wave forcing for August 2008. A small quantity of sediment is transported from Sites 1 and 2 by the tide and wind forcing. Figure 19 shows the sediment accretion and erosion pattern with wave forcing. The wave breaking at the shoreline has caused significant sediment movement in both nearshore and offshore, and there is very little change in the placement sites, indicating that the placed sediment was lesser mobilized in each site. 


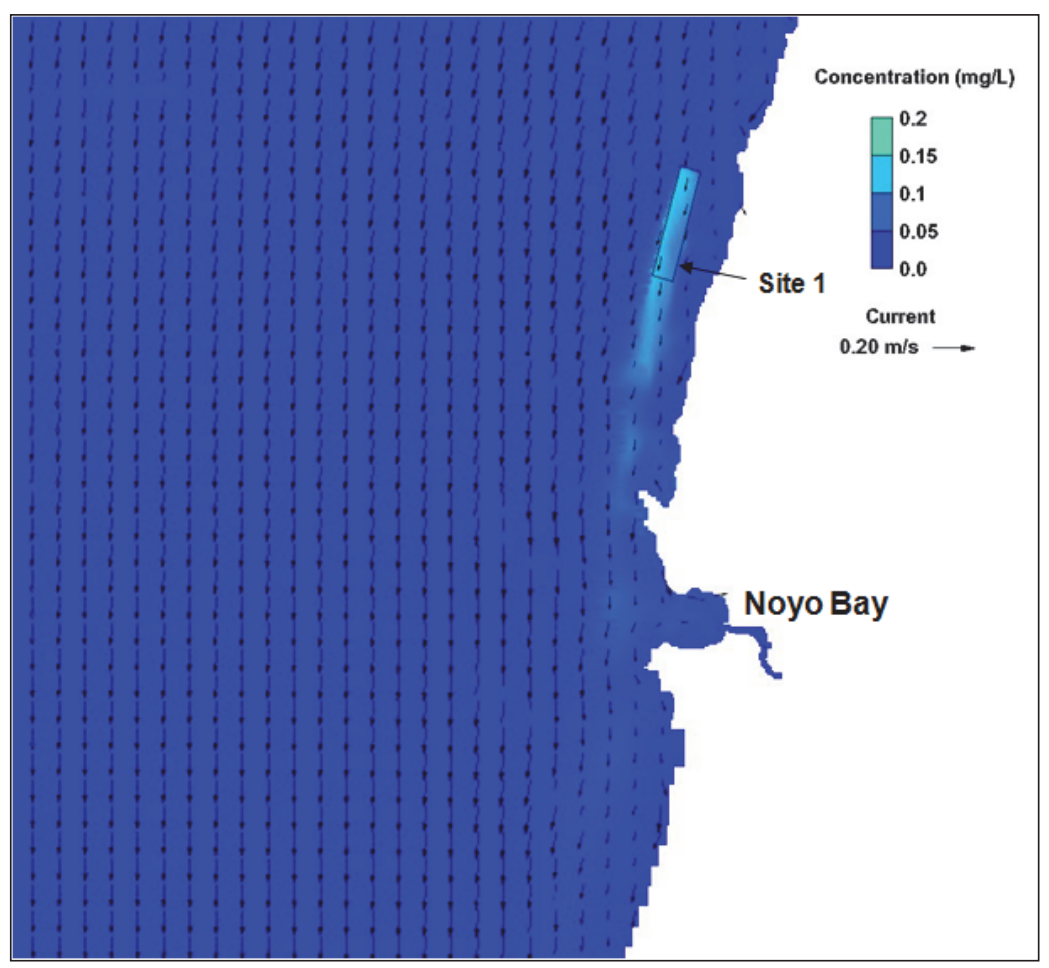

Figure 14. Calculated strong sediment concentration pattern from Site 1 placement without wave forcing for August 2008.

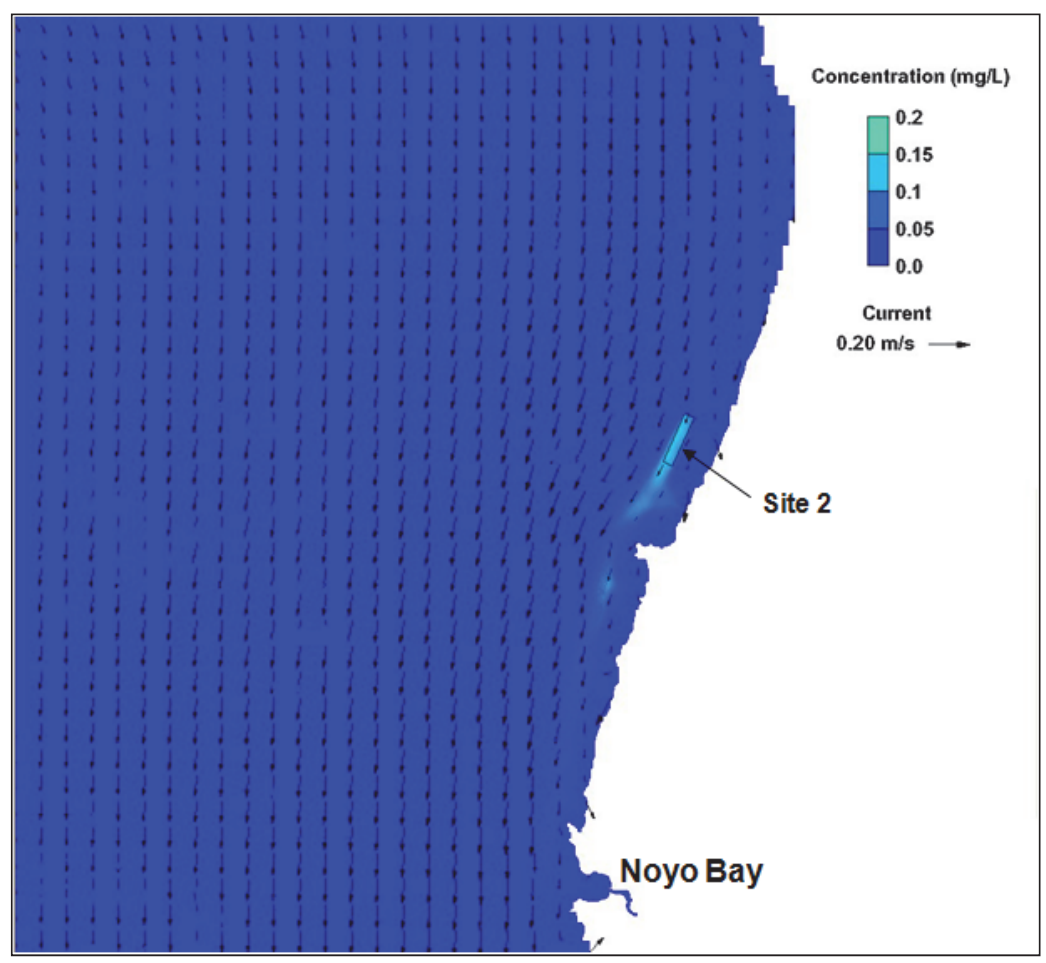

Figure 15. Calculated strong sediment concentration pattern from Site 2 placement without wave forcing for August 2008. 


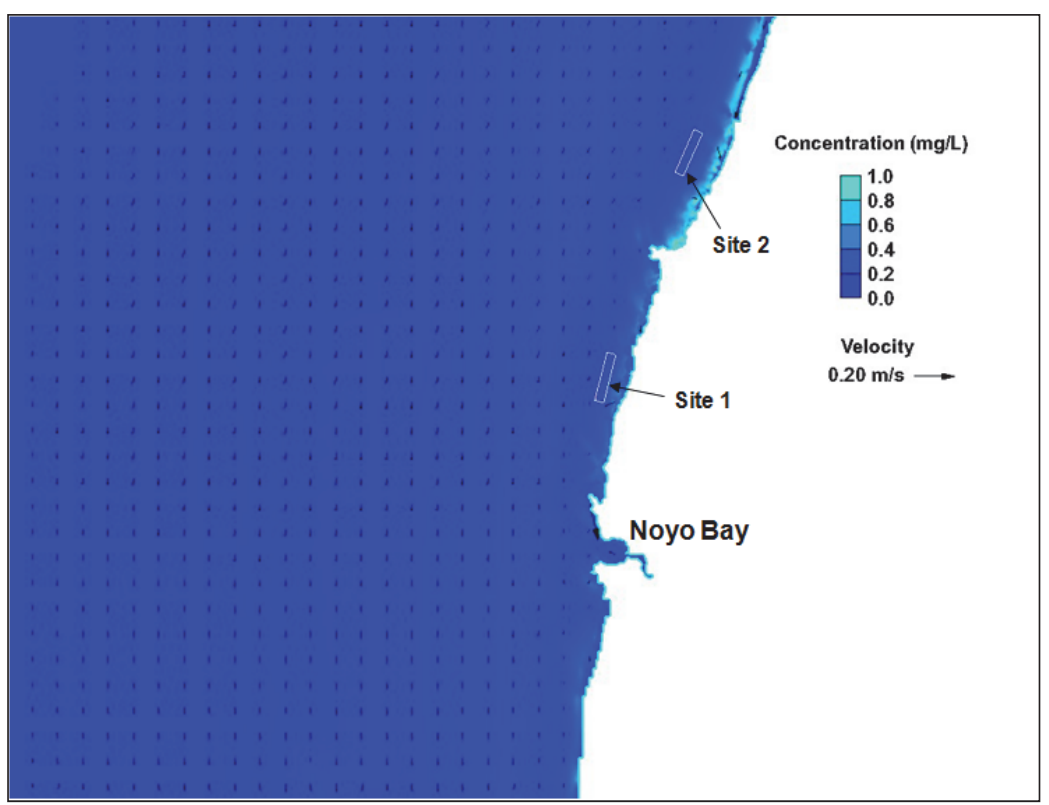

Figure 16. Calculated strong sediment concentration pattern with wave forcing for August 2008.

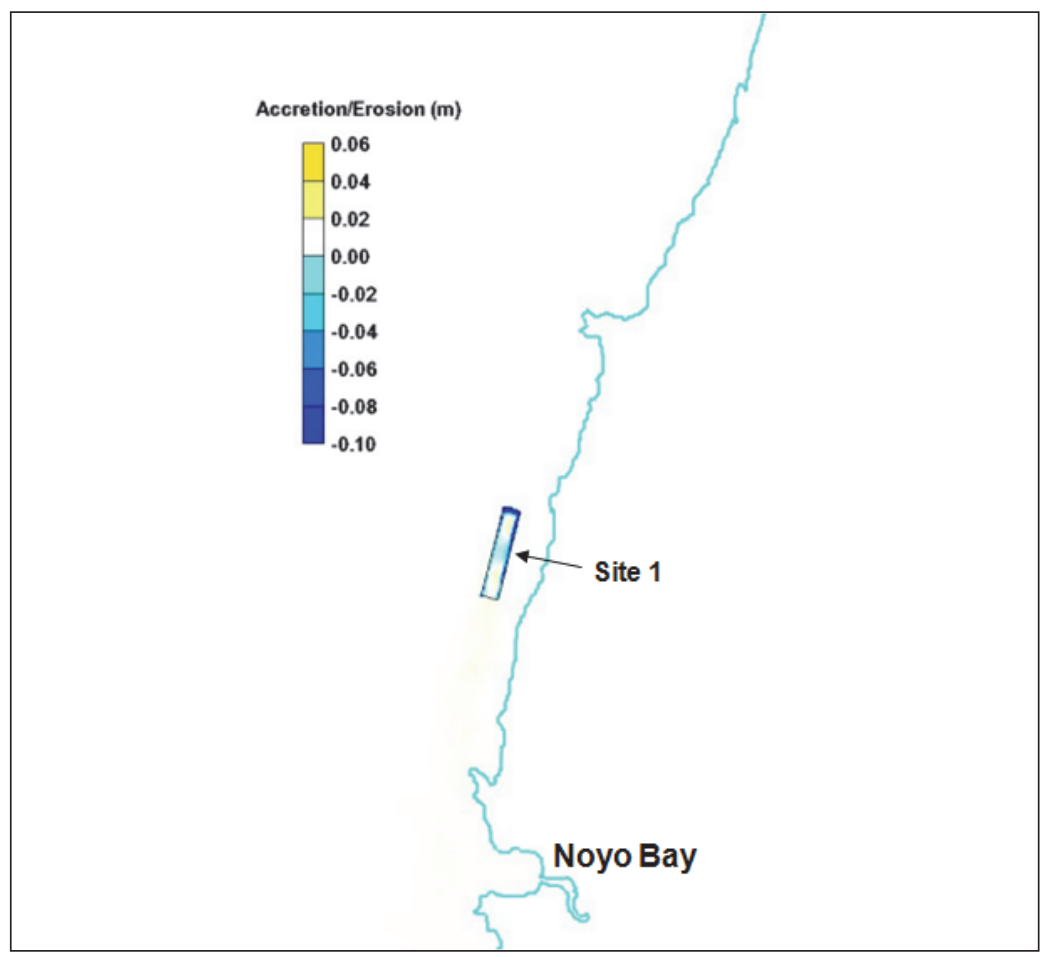

Figure 17. Calculated sediment accretion/erosion field at Site 1 without wave forcing for August 2008. 


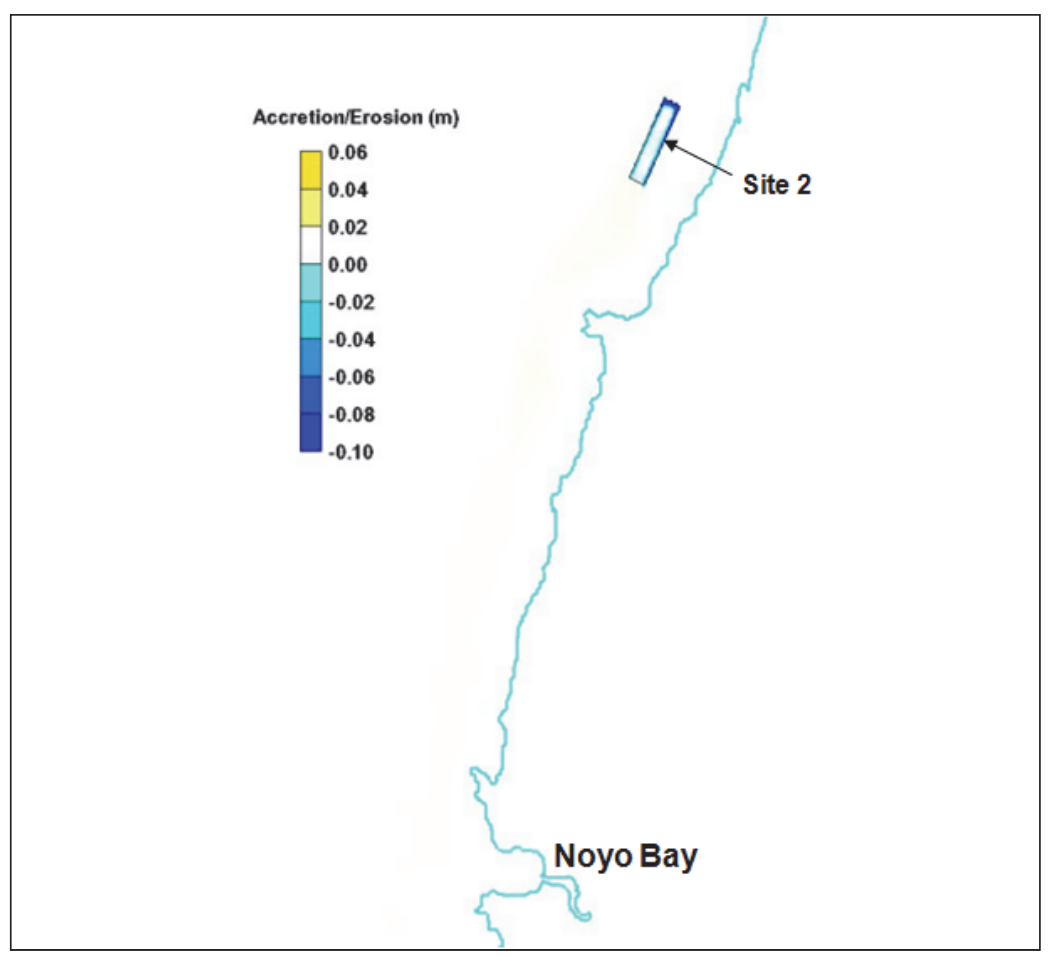

Figure 18. Calculated sediment accretion/erosion field at Site 2 without wave forcing for August 2008.

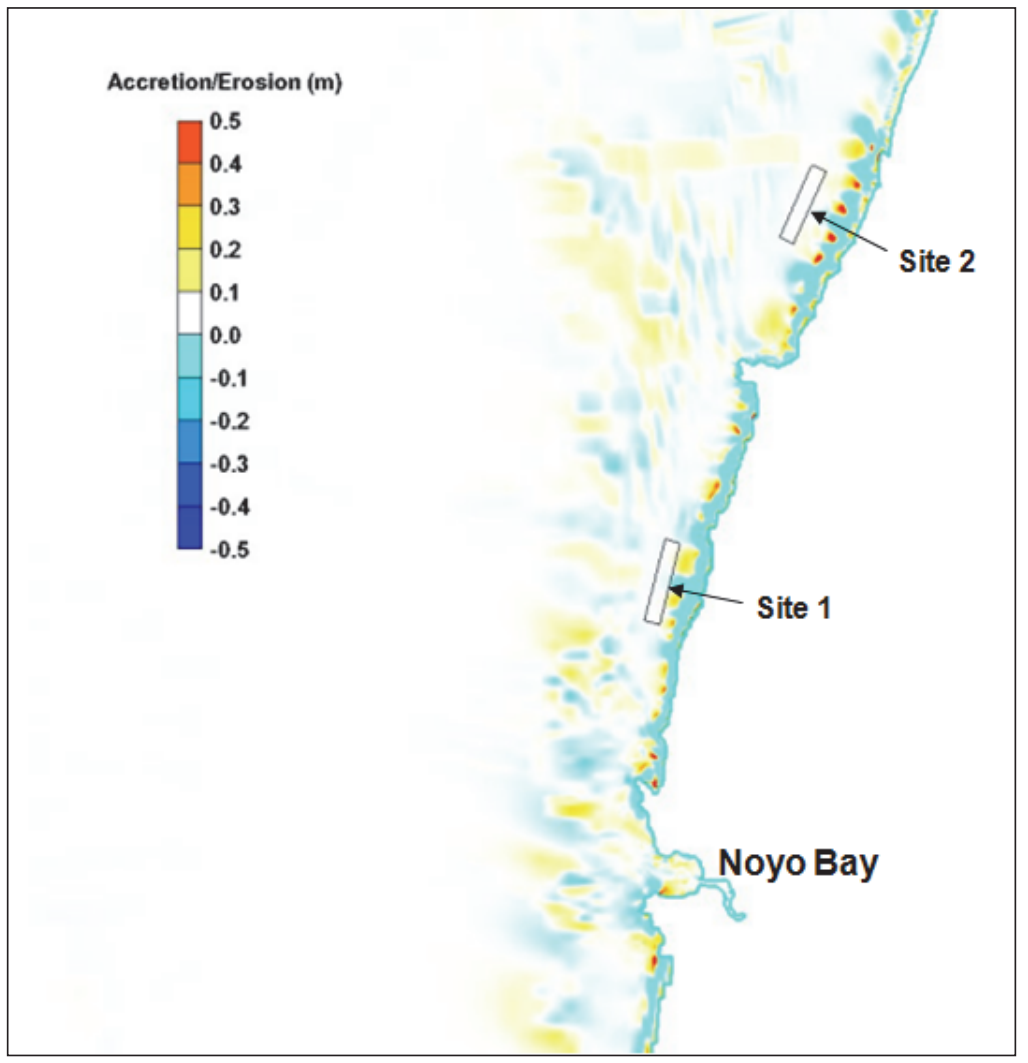

Figure 19. Calculated sediment accretion/erosion field with wave forcing for August 2008. 


\subsection{January 2009 simulation}

Figures 20 and 21 show snapshots of calculated sediment concentration from placement Sites 1 and 2, respectively, without the wave forcing for January 2009. The sediment concentration movement from Sites 1 and 2 follows the mean current direction, which is toward the south as a result of persisting northern wind in the northern California coast. Figure 22 shows a strong sediment transport pattern from Sites 1 and 2 with wave forcing. The sediment concentration in the nearshore is increased at Sites 1 and 2 as a result of large waves breaking in the surf zone, indicating that sediment transport at Sites 1 and 2 is overall small as compared to the significant sediment movement by waves in the nearshore.

Figures 23 and 24 show the calculated sediment accretion and erosion pattern at Site 1 and Site 2, respectively, without wave forcing. A small quantity of sediment is transported from Sites 1 and 2 by the tide and wind forcing. Figure 25 shows the sediment accretion and erosion pattern with wave forcing. The wave breaking at the shoreline in the winter has substantially increased the sediment movement in the nearshore as compared to the offshore region. Again, morphology change in the placement sites is negligible indicating little movement of the placed sediments in the region.

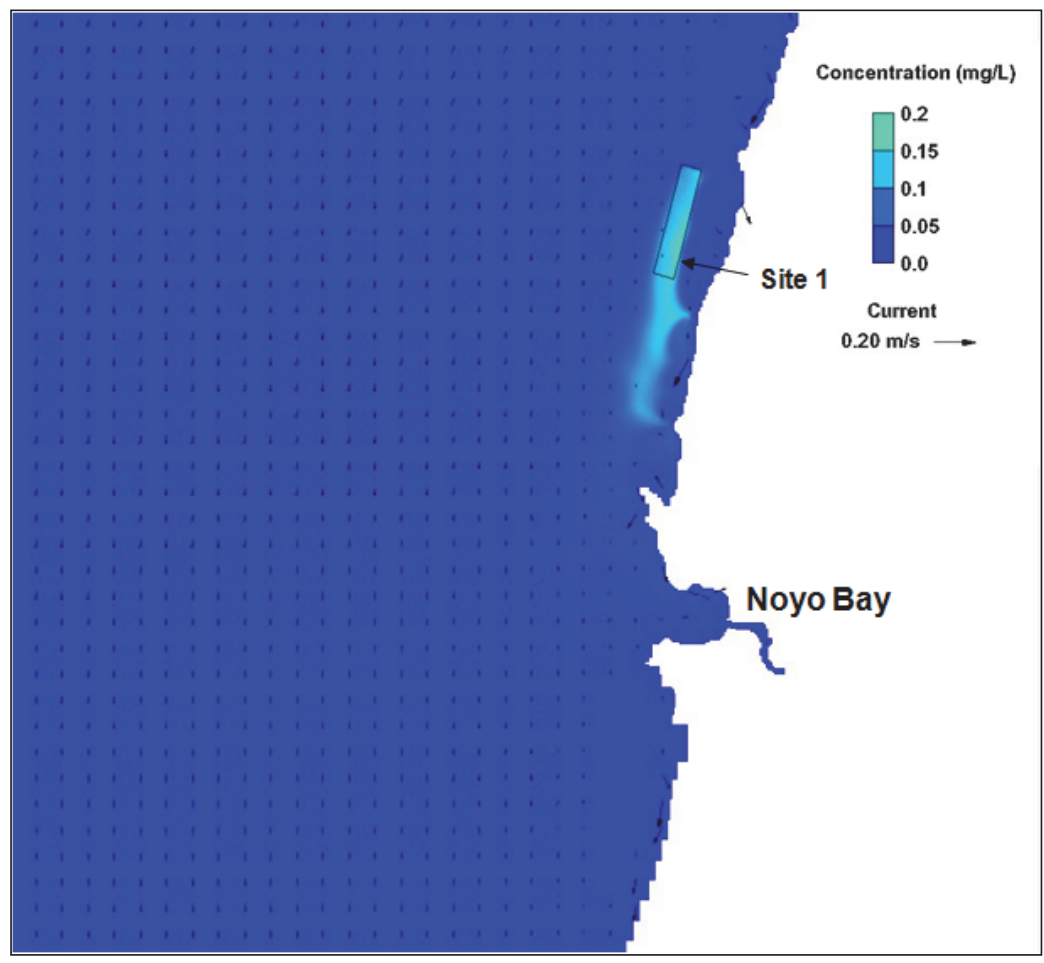

Figure 20. Calculated strong sediment concentration pattern from Site 1 placement without wave forcing for January 2009. 


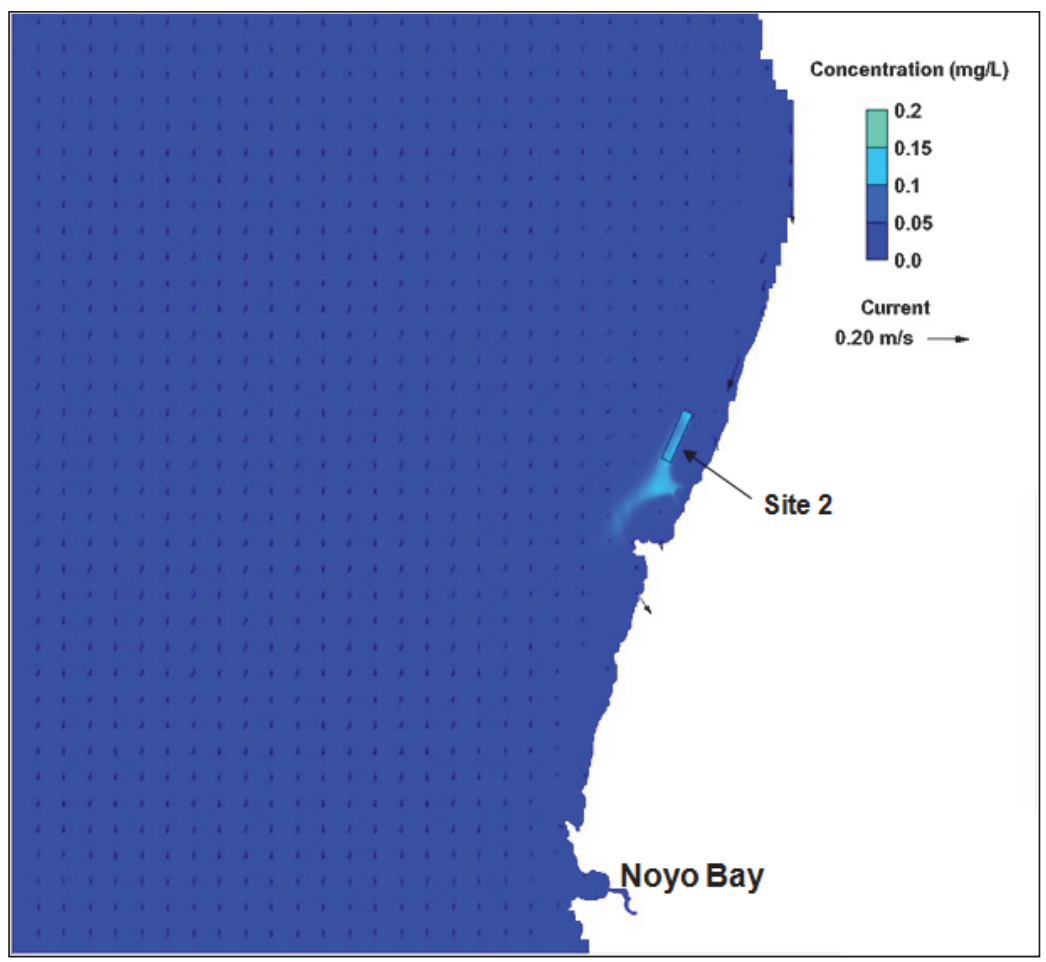

Figure 21. Calculated strong sediment concentration pattern from Site 2 placement without wave forcing for January 2009.

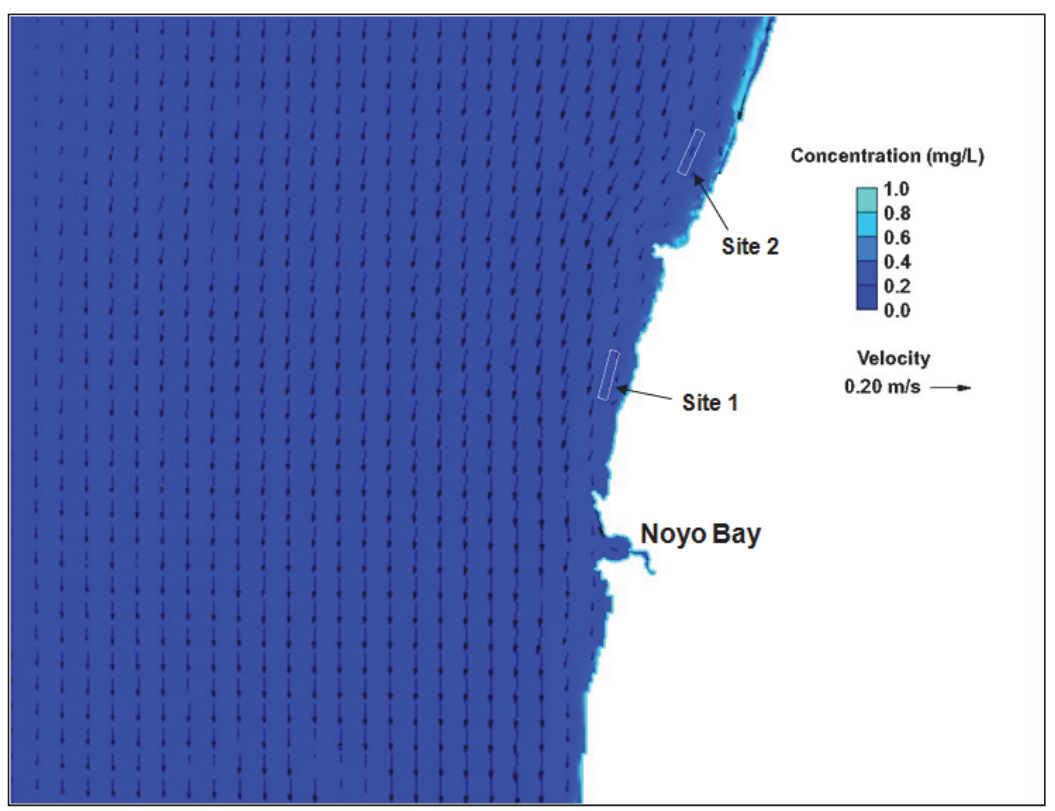

Figure 22. Calculated strong sediment concentration pattern from Site 1 or 2 placement with wave forcing for January 2009. 


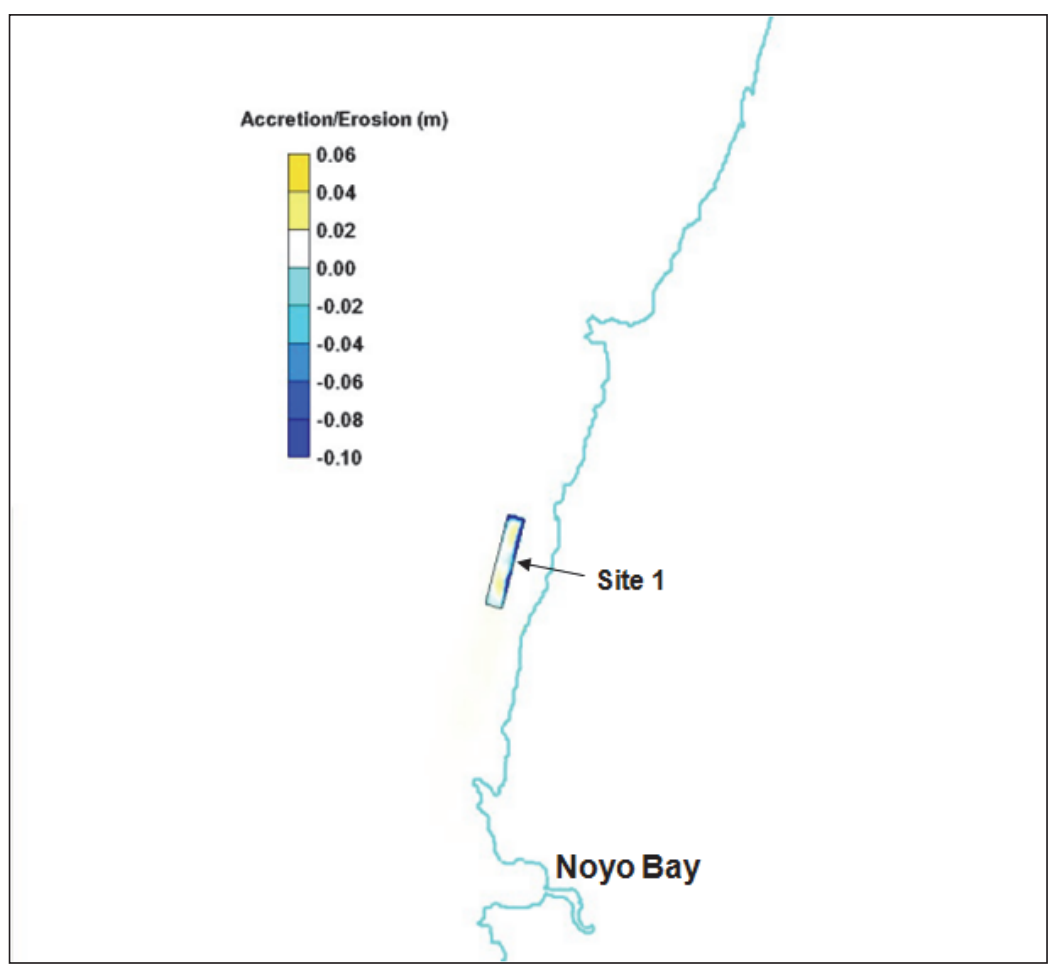

Figure 23. Calculated sediment accretion/erosion field at Site 1 without wave forcing for January 2009.

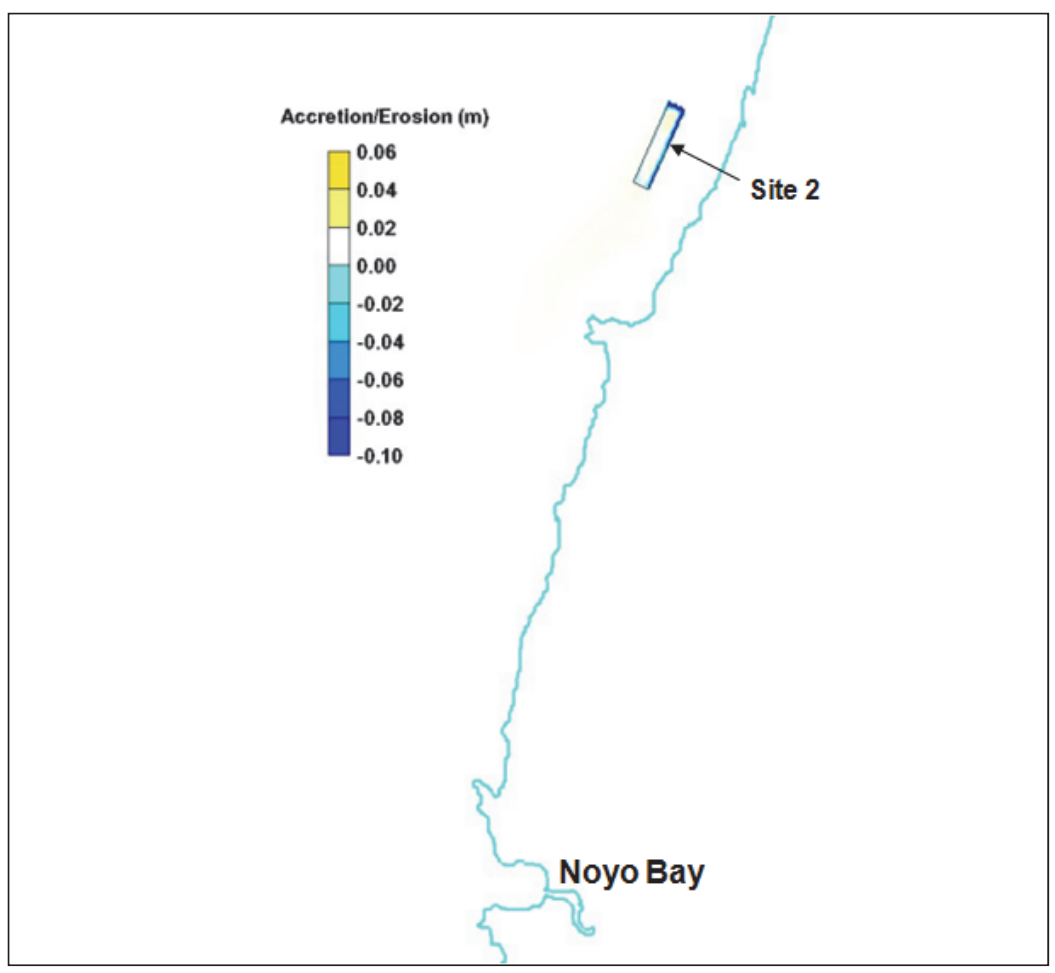

Figure 24. Calculated sediment accretion/erosion field at Site 2 without wave forcing for January 2009. 


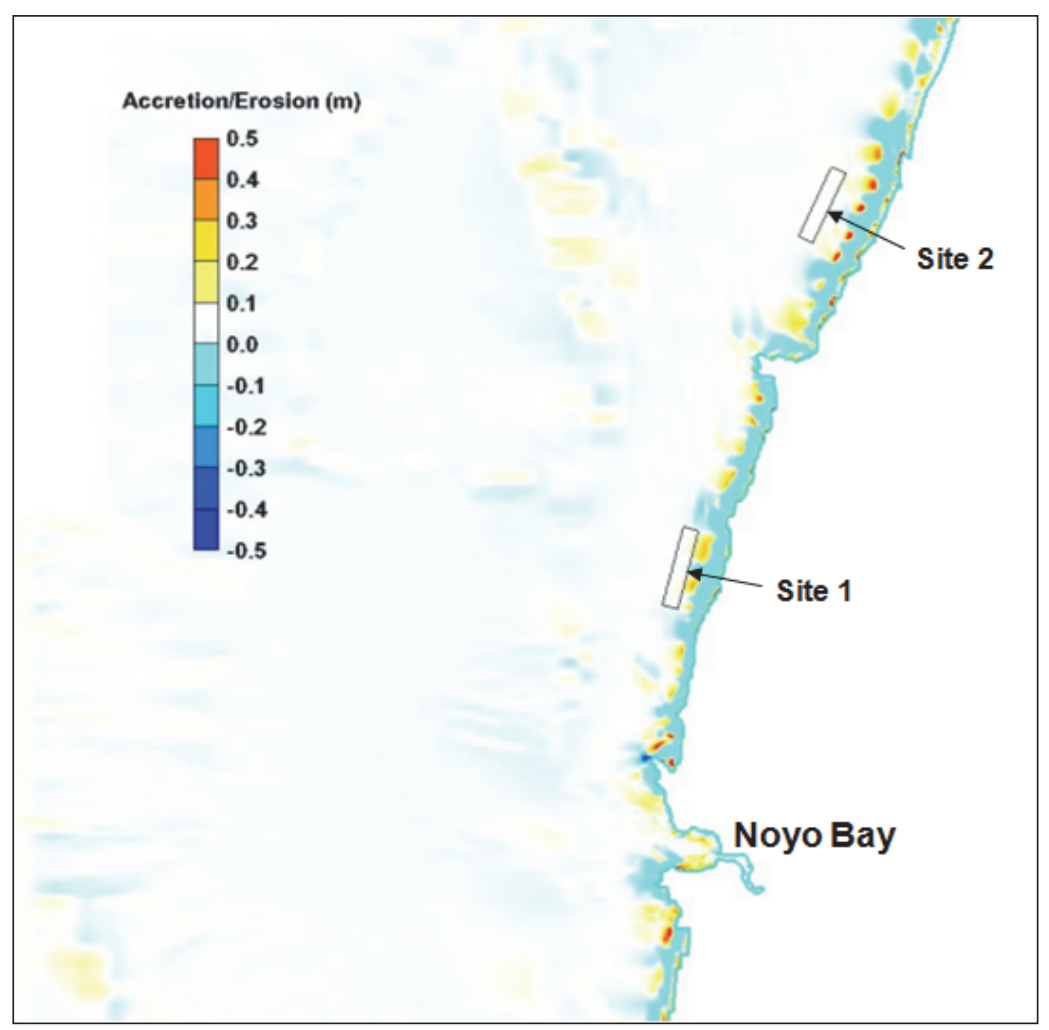

Figure 25. Calculated sediment accretion/erosion field with wave forcing for January 2009.

\subsection{Comparison of calculated morphology change}

The calculated morphology change for placement in Sites 1 and 2 were compared to the existing configuration based on simulation results for August 2008 and January 2009 described above. The comparison is for the model results with all forcings (tide, wind, and wave). Figures 26 and 27 show two areas, Areas A and B, that encompass Site 1 and Site 2, respectively, for the comparison of morphology change with the dredge material placement. Recalled 46,000 cu yd (35,000 cubic meters) of dredged material placement was designated for each of Sites 1 and 2. The background sediment accretion and erosion pattern shown in Figures 26 and 27 is for the August 2008 simulation.

Tables 5 and 6 present respectively the calculated morphology changes and percent differences for August 2008 and January 2009. The August 2008 simulation indicates a net gain of sediment in Areas A and B, and is slightly less (two percent smaller) with Sites 1 and 2 placement as compared to the existing configuration. The January 2009 simulation, on the other hand, shows a consistent net loss of sediment in Areas A and B. The difference of morphology change in Areas A and B with Site 1 or 2 placements is similar to the existing configuration. 


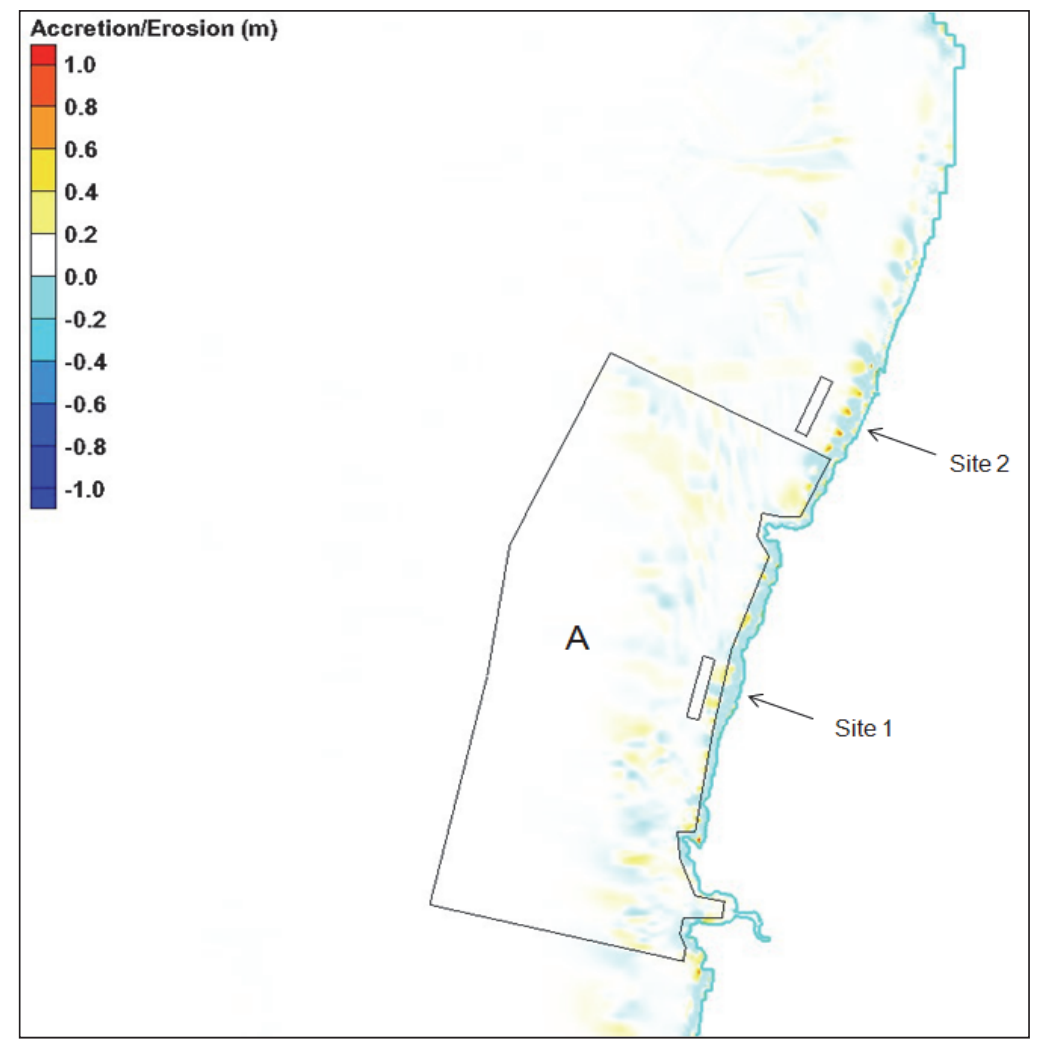

Figure 26. Area A encompassing Site 1.

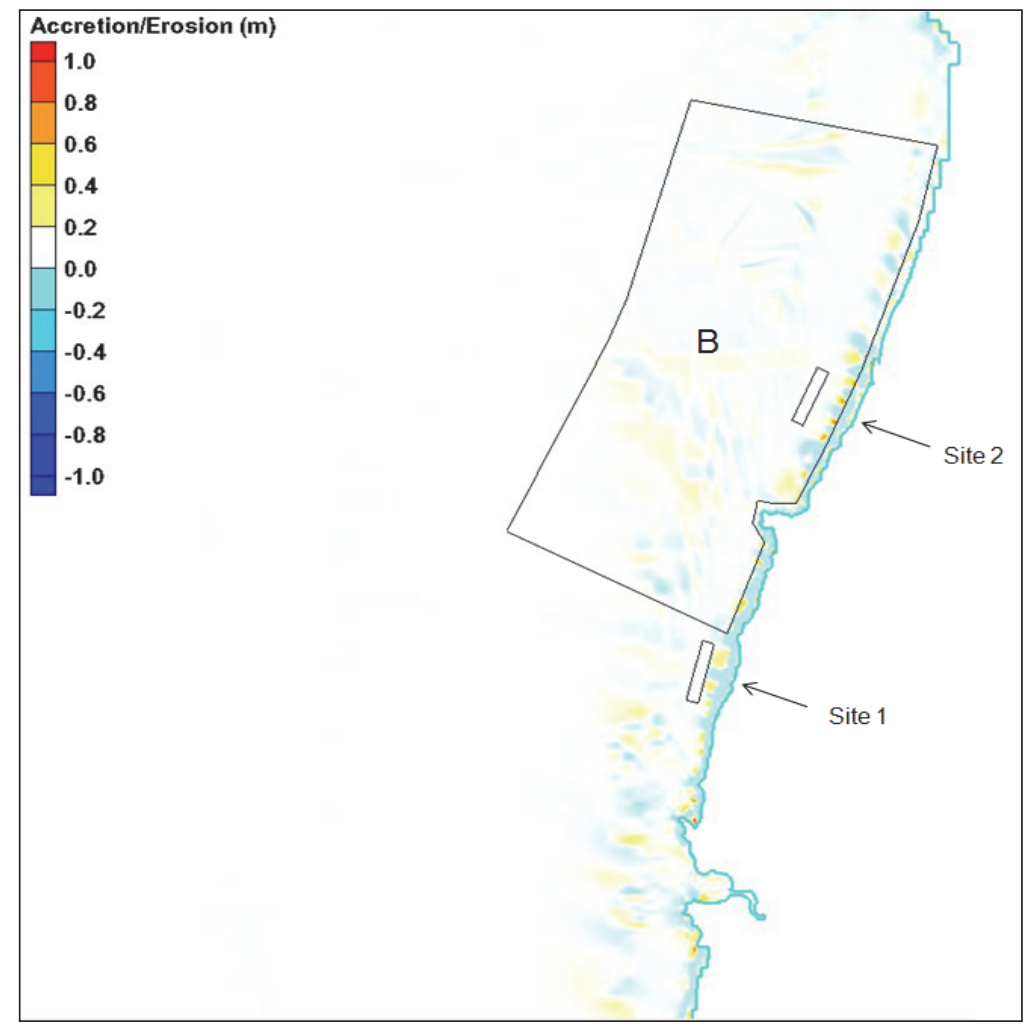

Figure 27. Area B encompassing Site 2. 
Table 5. Calculated morphology change and percent difference for August 2008.

\begin{tabular}{|l|l|l|}
\hline \multirow{2}{*}{ Placement Site } & \multicolumn{2}{|l|}{ Calculated Morphology Change (cu yd)* } \\
\cline { 2 - 3 } & Area A & Area B \\
\hline None & 60,830 & 16,400 \\
\hline Site 1 & 59,850 & 16,280 \\
& $(-1.6 \%)$ & $(-0.7 \%)$ \\
\hline Site 2 & 59,700 & 16,250 \\
& $(-1.8 \%)$ & $(-0.9 \%)$ \\
\hline
\end{tabular}

* Percent difference in parentheses is compared to the existing configuration

Table 6. Calculated morphology change and percent difference for January 2009.

\begin{tabular}{|l|l|l|}
\hline \multirow{2}{*}{ Placement Site } & \multicolumn{2}{|l|}{ Calculated Morphology Change (cy)* } \\
\cline { 2 - 3 } & Area A & Area B \\
\hline None & $-186,560$ & $-157,930$ \\
\hline Site 1 & $-186,490$ & $-157,860$ \\
& $(-0.04 \%)$ & $(-0.05 \%)$ \\
\hline Site 2 & $-186,620$ & $-157,980$ \\
& $(0.03 \%)$ & $(0.03 \%)$ \\
\hline
\end{tabular}

* Percent difference in parentheses is compared to the existing configuration

\subsection{PTM simulations}

The PTM was used to simulate sediment motion during and after release of sediment from the barge. The CMS flow and wave results were input to PTM to calculate the clay and silt particle movement. This simulation excludes the fine sand particles as the sand has quickly settled to the sea bed at the placement site at depths between 40 and $60 \mathrm{ft}$ (12 to $28 \mathrm{~m}$ ) as calculated by STFATE.

PTM simulated the particle release and pathways of clay and silt materials at the north end of Site 1 for August 2008, with the sediment particles released twice a day in the first 12 days of a 30-day simulation. Total volumes of clay and silt released in the simulations are approximately 105 and $155 \mathrm{cu}$ yd, respectively. It should be noted that the total percentage of clay and silt is small (less than 20 percent) as compared to the majority of sand in the dredge material. 
Figures 28 and 29 show the snapshot of calculated clay particle distributions at the end of the release (day 12) and the end of simulation (day 30), respectively. Note that by day 30 (Figure 29), clay particles have moved into the nearshore north of Noyo, although some have moved south and offshore. Figures 30 and 31 are snapshots of calculated silt particle distributions at the end of the release (day 12) and the end of simulation (day 30), respectively. These simulations show both clay and silt particles either follow the waves propagating towards shore or move southward driven by the northerly wind during this summer period. A large portion of the fine sediments can move southward past Noyo Bay, and some move permanently out of the model domain in the simulation period. Comparing to silt particles, less clay particles are left within the domain at the end of the simulation (Figures 29 and 31).

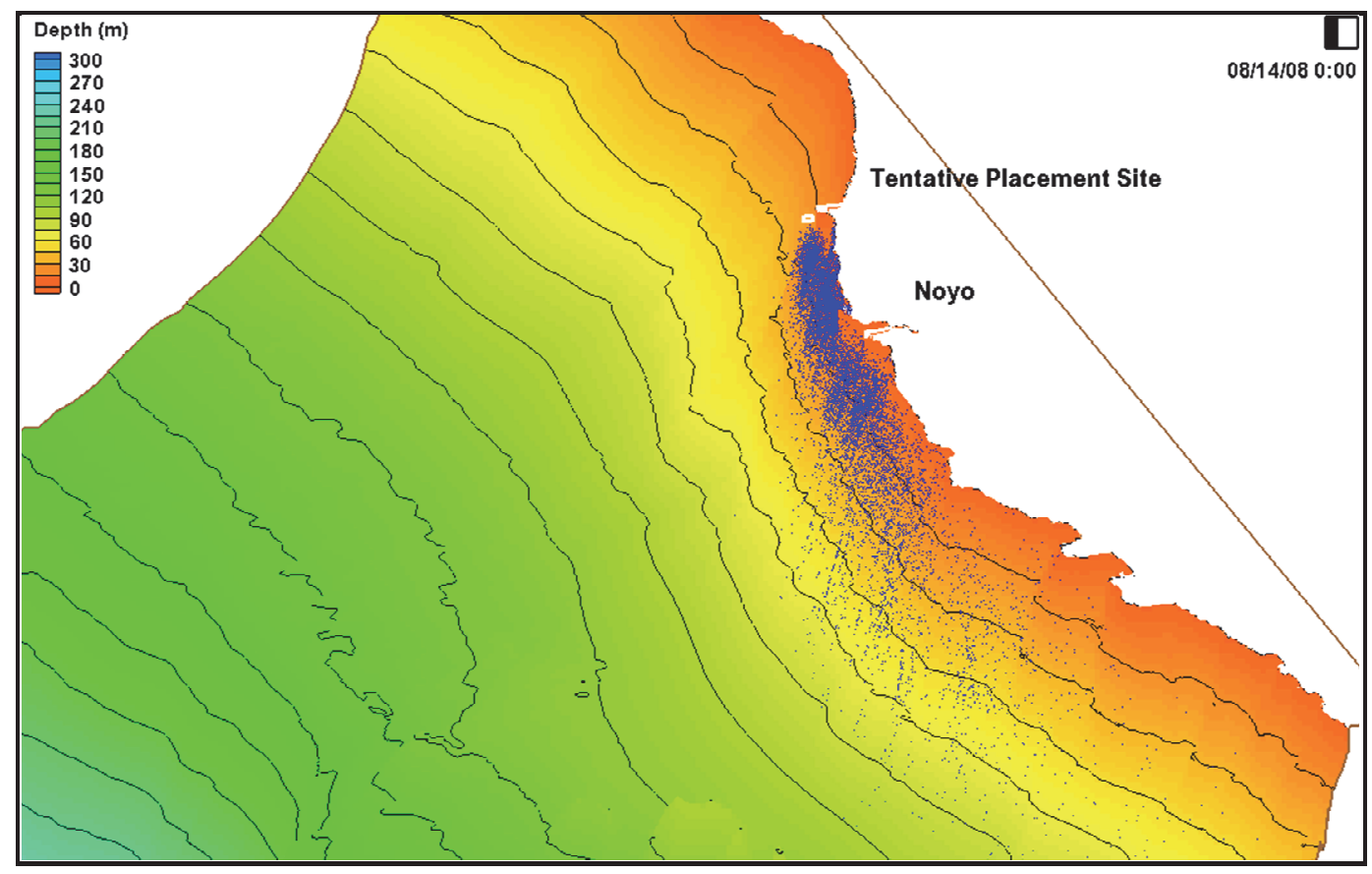

Figure 28. Calculated clay particle distribution at the end of the release (day 12). 


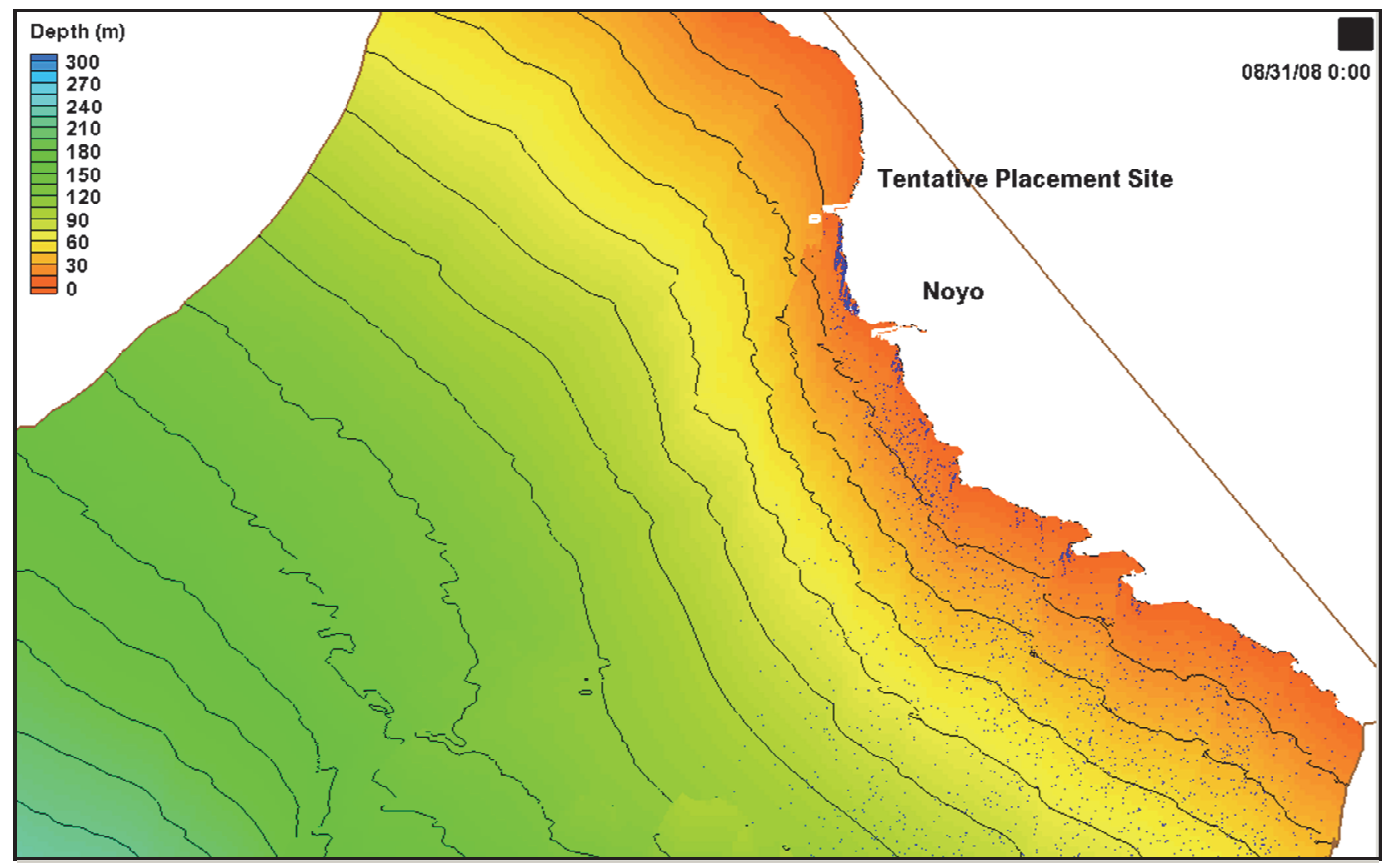

Figure 29. Calculated clay particle distribution at the end of simulation (day 30).

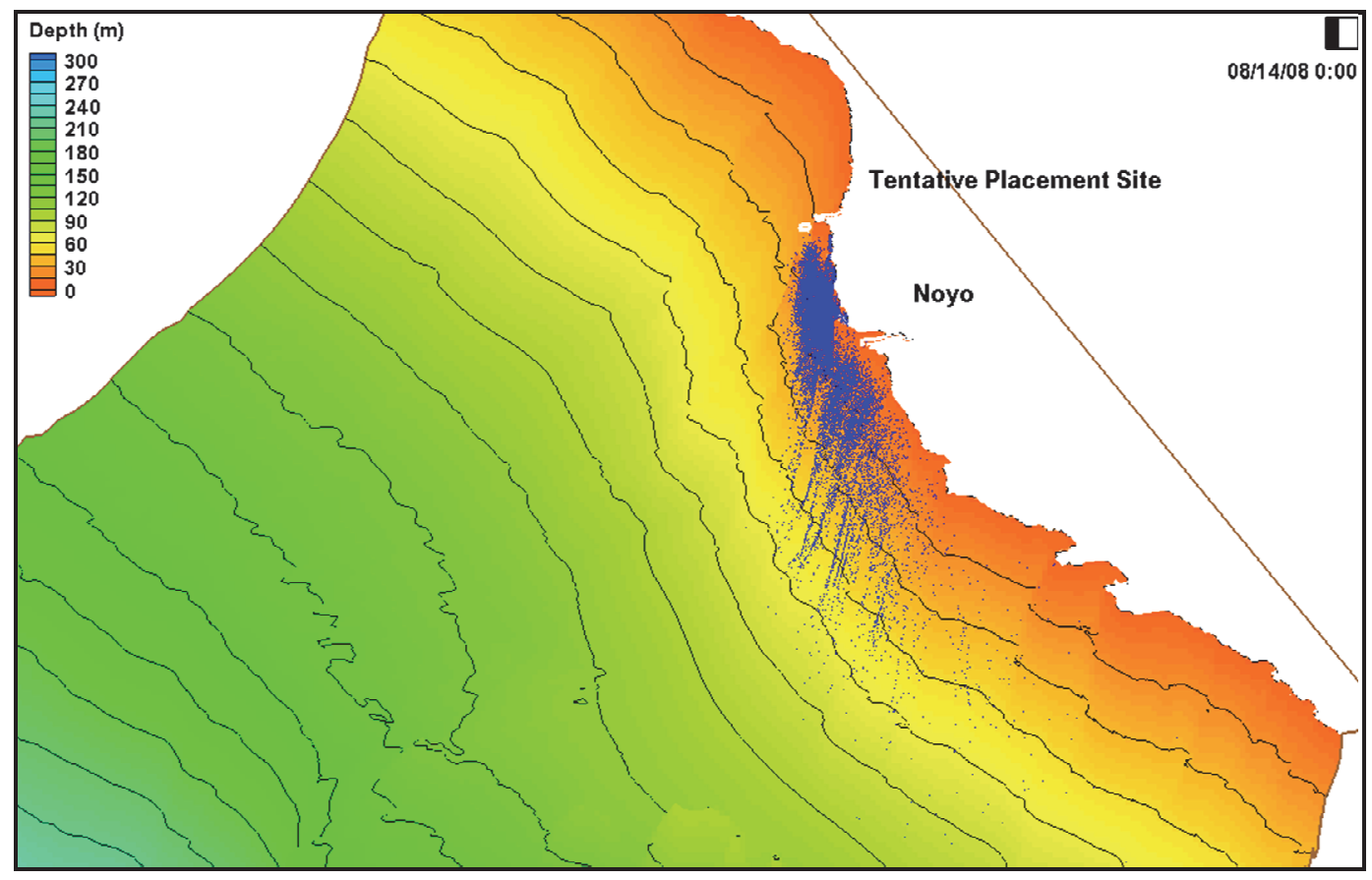

Figure 30. Calculated silt particle distribution at the end of the release (day 12). 


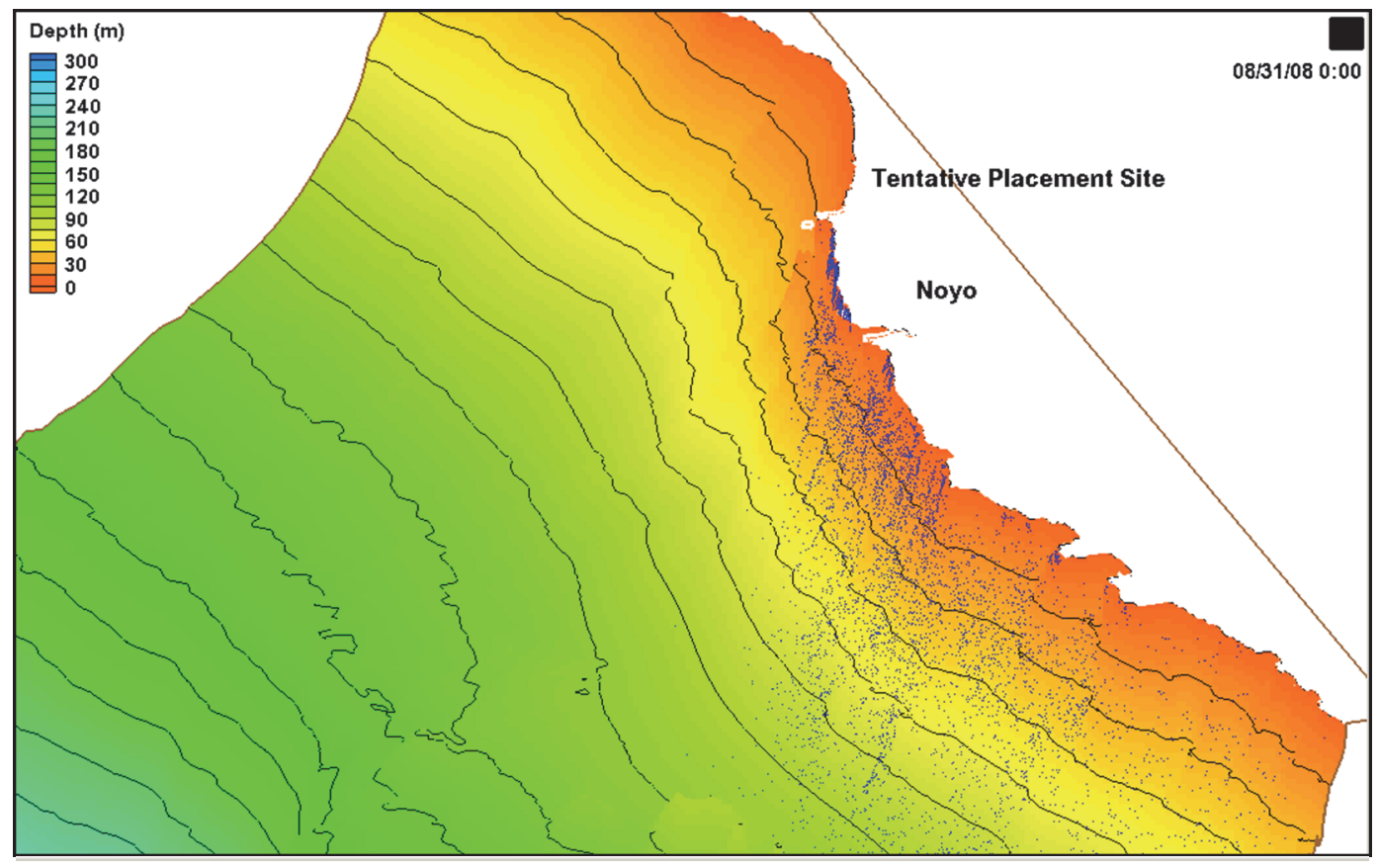

Figure 31. Calculated silt particle distribution at the end of simulation (day 30). 


\section{Conclusions}

The PTM, STFATE, and CMS, a coupled wave, flow and sediment transport numerical modeling system were applied to simulate placement of dredged sediment placed north of Noyo Bay, CA, in the nearshore. The simulations included two placement locations, Sites 1 and 2, approximately two and five miles north of the bay entrance, respectively (Figure 13). Each site covered a rectangular area of $700 \mathrm{ft} \times 3,700 \mathrm{ft}(210 \mathrm{~m} \mathrm{x} 1,120 \mathrm{~m})$ at depths between 40 and $60 \mathrm{ft}$ (12 and $18 \mathrm{~m}$ ). A dredge material volume of 46,000 cu yd (35,000 cubic meters) was placed at either Site 1 or 2 in these simulations. Numerical simulations were conducted for tide, wind input and with and without the wave forcing to evaluate the sediment transport at the placement sites.

The CMS simulations for August 2008 and January 2009, representing a normal summer month and a mild winter month, respectively, indicated that coastal processes at the coast of the Mendocino County, CA, were more dominated by waves than tides and wind-driven currents. The calculated morphology change as result of tide, wind-driven current, and waves was more significant in the nearshore because of wave breaking than at two placement sites located at depths of 40 to $60 \mathrm{ft}$ (12 and $18 \mathrm{~m}$ ). The effect of placing dredged sediment at the two proposed sites is insignificant as compared to the existing configuration without the dredge material placement. The simulation indicated overall mild sediment accretion at the coast in August 2008 and significant erosion in January 2009 because of large long waves that occur in the winter months. The calculation of clay and silt particle movement by the PTM showed that the fine sediments moved towards the shore by wave motion or southward by the wind-driven current parallel to the coastline. This study has served to improve the interface for coupling the CMS and PTM. The improved modeling technology will be used in other Corps projects.

Because recent bathymetry and bedrock data were unavailable to represent nearshore sea bottom characteristics accurately, results from the present numerical modeling study should be considered preliminary, and more research is needed to determine short- and long-term sediment transport and morphology change trends at these two placement sites. A field data collection program is presently underway and the final model simulations will be conducted based on the updated bathymetry surveys, and numerical models will be calibrated with newly measured field data for flow, wave, and sediments. 


\section{References}

Buttolph, A. M., C. W. Reed, N. C.Kraus, N. Ono, M. Larson, B. Camenen, H. Hanson, T. Wamsley, and A. K. Zundel. 2006. Two-dimensional depth-averaged circulation model CMS-M2D: Version 3.o, Report 2, sediment transport and morphology change. Coastal and Hydraulics Laboratory Technical Report ERDC/CHL-TR06-7, U.S. Army Engineer Research and Development Center, Coastal and Hydraulics Laboratory, Vicksburg, MS.

Demirbilek, Z. and J. Rosati. 2011. Verification and Validation of the Coastal Modeling System, Report 1: Executive Summary, ERDC/CHL-TR-11-10, US Army Engineer Research and Development Center, Coastal and Hydraulics Laboratory, Vicksburg, Mississippi

Demirbilek, Z., K.J. Connell, N.J. MacDonald, and A. K. Zundel. 2008. Particle Tracking Model (PTM) in SMS10: IV. Link to Coastal Modeling System, ERDC/CHL CHETN-IV-71, U.S. Army Engineer Research and Development Center, Coastal and Hydraulics Laboratory, Vicksburg, MS.

Inman, D.L. and J.D. Frautschy. 1966. Littoral processes and the development of shorelines. Proc. Coastal Engin. Specialty Conf. ASCE, p. 511-536.

Johnson, B.H. 1990. User's Guide for Models of Dredged Material Disposal in Open Water. Environmental Laboratory Technical Report TR-D-90-5. U.S. Army Waterways Experiment Station, Vicksburg, MS.

Lin, L., Z. Demirbilek, R. Thomas, and J. Rosati III. 2011. Verification and Validation of the Coastal Modeling System, Report 2: CMS-Wave, ERDC/CHL-TR-11-10, US Army Engineer Research and Development Center, Coastal and Hydraulics Laboratory, Vicksburg, Mississippi

Lin, L., and Z. Demirbilek. 2010. CMS: A Coastal Modeling System for inlets and navigation projects. Proceedings of the $5^{\text {th }}$ International Ocean-Atmosphere Conference.

Lin, L., Z. Demirbilek, H. Mase, J. Zheng, and F. Yamada. 2008. CMS-Wave: A nearshore spectral wave processes model for coastal inlets and navigation projects. Coastal and Hydraulics Laboratory Technical Report ERDC/CHL-TR08-13, U.S. Army Engineer Research and Development Center, Coastal and Hydraulics Laboratory, Vicksburg, MS.

Lin, L., J. Rosati III, and Z. Demirbilek. 2012. CMS-Wave Model: Part 5. Full-plane wave transformation and grid nesting. Coastal and Hydraulics Laboratory Technical Note ERDC/CHL CHETN-IV-81, U.S. Army Engineer Research and Development Center, Coastal and Hydraulics Laboratory, Vicksburg, MS.

Patsch, K. and G. Griggs. 2006. Littoral cells, sand budgets, and beaches: understanding California's shoreline. Institute of Marine Science, University of California, Santa Cruz. 
U .S. Army Corps of Engineers. 2009. Results of chemical, physical and biological testing of sediments from Noyo River and Harbor Channels. Prepared by Weston Solutions.

Zundel, A. K., 2006. Surface-water modeling system reference manual - Version 9.2. Provo, UT: Brigham Young University Environmental Modeling Research Laboratory. 


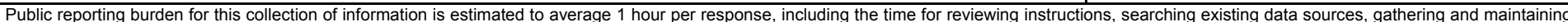

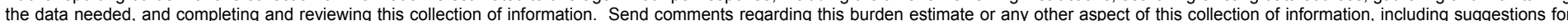

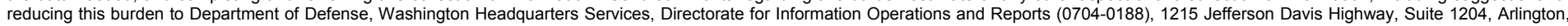

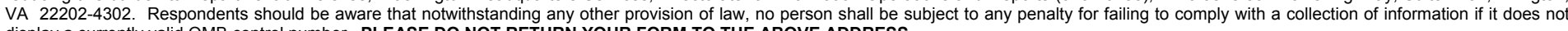
display a currently valid OMB control number. PLEASE DO NOT RETURN YOUR FORM TO THE ABOVE ADDRESS.
1. REPORT DATE (DD-MM-YYYY) 2. REPORT TYPE
3. DATES COVERED (From - To)

February 2013 Final

\section{TITLE AND SUBTITLE}

Pilot Study Evaluating Nearshore Sediment Placement Sites, Noyo Harbor, CA

5a. CONTRACT NUMBER

5b. GRANT NUMBER

5c. PROGRAM ELEMENT NUMBER

\section{AUTHOR(S)}

5d. PROJECT NUMBER

Lihwa Lin, Honghai Li, Mitchell E. Brown, Frank Wu, Lisa Andes

5e. TASK NUMBER

5f. WORK UNIT NUMBER

\section{PERFORMING ORGANIZATION NAME(S) AND ADDRESS(ES)}

8. PERFORMING ORGANIZATION REPORT

Coastal and Hydraulics Laboratory

US Army Engineer Research and Development Center NUMBER

3909 Halls Ferry Road

ERDC/CHL TR-13-2

Vicksburg, MS 39180-6199, USA

\section{SPONSORING / MONITORING AGENCY NAME(S) AND ADDRESS(ES)}

10. SPONSOR/MONITOR'S ACRONYM(S)

U.S. Army Engineer District, San Francisco

1455 Market Street

San Francisco, CA 94103, USA

11. SPONSOR/MONITOR'S REPORT NUMBER(S)

\section{DISTRIBUTION / AVAILABILITY STATEMENT}

Approved for public release; distribution is unlimited.

\section{SUPPLEMENTARY NOTES}

\section{ABSTRACT}

The US Army Engineer District, San Francisco (SPN) and the Coastal Inlets Research Program conducted a pilot study to consider various placement locations for dredged material in vicinity of Noyo Harbor, CA. Approximately 30,000-40,000 cu yd/yr of beachquality sediment is dredged from the navigation channel and the lower Noyo River, located on the north central California coast. The pilot study investigated several potential locations for placement of dredged sediments in one of two areas north of Noyo Bay. The investigation included field data collection and numerical modeling of near-field sediment transport and suspended sediment concentration during and after placement of the dredged sediments under combined wave and current conditions. The numerical model provided the technical information necessary for SPN and Noyo Harbor stakeholders to evaluate a location site that is economically feasible for the optimum sediment placement. Upon acceptance by the stakeholders and receipt of additional funds, a demonstration project will be conducted, and the Dredged Material Management Plan (DMMP) for Noyo Harbor will be updated to include a beneficial use site for nearshore placement.

\begin{tabular}{|c|c|c|c|c|c|}
\hline \multicolumn{2}{|c|}{ 15. SUBJECT TERMS } & \multicolumn{2}{|l|}{ Noyo Harbor } & \multicolumn{2}{|c|}{ Sediment transport } \\
\hline \multicolumn{2}{|c|}{ Coastal processes } & \multicolumn{2}{|c|}{ Numerical modeling } & \multicolumn{2}{|c|}{ Tidal and wind forcing } \\
\hline \multicolumn{2}{|c|}{ Dredged material placement } & \multicolumn{2}{|c|}{ Particle tracking } & \multicolumn{2}{|c|}{ Wave transformation } \\
\hline \multicolumn{3}{|c|}{ 16. SECURITY CLASSIFICATION OF: } & $\begin{array}{l}\text { 17. LIMITATION } \\
\text { OF ABSTRACT }\end{array}$ & $\begin{array}{l}\text { 18. NUMBER } \\
\text { OF PAGES }\end{array}$ & $\begin{array}{l}\text { 19a. NAME OF RESPONSIBLE } \\
\text { PERSON: Lihwa Lin }\end{array}$ \\
\hline $\begin{array}{l}\text { a. REPORT } \\
\text { Unclassified }\end{array}$ & $\begin{array}{l}\text { b. ABSTRACT } \\
\text { Unclassified }\end{array}$ & $\begin{array}{l}\text { c. THIS PAGE } \\
\text { Unclassified }\end{array}$ & Unclassified & 44 & $\begin{array}{l}\text { 19b. TELEPHONE NUMBER (include } \\
\text { area code) } \\
\text { (601) 634-2704 }\end{array}$ \\
\hline
\end{tabular}

